\begin{tabular}{|c|c|c|}
\hline Beitr. Ent. & Keltern & ISSN 0005-805X \\
\hline $\mathbf{6 2}(2012) 2$ & S. $299-330$ & 20.12 .2012 \\
\hline
\end{tabular}

\title{
The Pseudolathra species of the East Palaearctic and the Oriental regions
}

\section{(Coleoptera: Staphylinidae: Paederinae)}

With 70 figures and 3 maps

Volker Assing

\section{Summary}

The available types and additional material of the species of the lathrobiine genus Pseudolathra CASEY, 1905 of the East Palaearctic (including Middle Asia) and the Oriental regions are revised. In all, thirteen valid species are recognised, six of which are new to science: P. brevincisa sp. n. (Thailand), P. cordiformis sp. n. (SE-India), P. himalayana sp. n. (Pakistan, N-India, Nepal), P. sagittata sp. n. (Thailand), P. transversicollis sp. $\mathrm{n}$. (Thailand, N-India), and P. vellicans sp. n. (N-India). All the species of the study region are (re-)described or diagnosed; thirteen species are illustrated. Pseudolathra pulchella (Kraatz, 1859), previously a synonym of $P$. caffra (BoHEMAN, 1848), is revalidated. Two synonymies are proposed: Pseudolathra pulchella (KraAtz, 1859) = P. caffra javana (CAmeron, 1940), syn. n.; P. unicolor (KraAtz, $1859)=$ P. chujoi (Last, 1966), syn. n. Two species are moved from Lobrathium Mulsant \& Rey, 1878 to Pseudolathra: P. nigerrima (CAMERon, 1924), comb. n., and P. regularis (Sharp, 1889), comb. $\mathrm{n}$. The East Palaearctic and Oriental species on the one hand and the West Palaearctic species on the other hand form separate phylogenetic lineages. The former are tentatively attributed to the subgenus Allolathra Coiffait, 1972 and the latter to the nominate subgenus. The species of the East Palaearctic and Oriental regions are assigned to three species groups. A key to species and a catalogue are provided. Additional records are reported, among them several new country records. The distributions of twelve species are mapped.

\section{Key words}

Coleoptera, Staphylinidae, Paederinae, Lathrobiina, Pseudolathra, Palaearctic region, Oriental region, taxonomy, new species, new combinations, new generic assignments, new synonymies, key to species, catalogue, distributions.

\section{New species}

Pseudolathra brevincisa sp. n., P. cordiformis sp. n., P. himalayana sp. n., P. sagittata sp. n., P. transversicollis sp. n., P. vellicans sp. n.

\section{Zusammenfassung}

Die verfügbaren Typen und weiteres Material der in der Ostpaläarktis und der Orientalis verbreiteten Arten der Lathrobiinen-Gattung Pseudolathra CASEY, 1905 werden revidiert. Die Gattung ist in diesen Regionen mit insgesamt dreizehn Arten vertreten, sechs davon sind neu: P. brevincisa sp. n. (Thailand), P. cordiformis sp. n. (südöstliches Indien), P. himalayana sp. n. (Pakistan, Nordindien, Nepal), P. sagittata 
sp. n. (Thailand), P. transversicollis sp. n. (Thailand, Nordindien) und $P$. vellicans sp. n. (Nordindien). Alle behandelten Arten werden beschrieben bzw. redeskribiert; dreizehn Arten werden abgebildet. Pseudolathra pulchella (KRAATZ, 1859), bisher Synonym von P. caffra (Boheman, 1848), wird revalidiert. Zwei Namen werden synonymisiert: Pseudolathra pulchella (KraAtZ, 1859) = P. caffra javana (CAmeron, 1940), syn. n.; P. unicolor (KraAtz, 1859) $=$ P. chujoi (Last, 1966), syn. n. Zwei bislang Lobrathium Mulsant \& Rey, 1878 zugeordnete Arten werden in die Gattung Pseudolathra gestellt: P. nigerrima (Cameron, 1924), comb. n., und P. regularis (SHARp, 1889), comb. n. Die ostpaläarktischen und orientalischen Arten einerseits und die westpaläarktischen Arten andererseits bilden separate phylogenetische Linien. Erstere werden vorläufig der Untergattung Allolathra CoIfFAIT, 1972 gestellt, Letztere der Untergattung Pseudolathra zugeordnet. Die in der Ostpaläarktis und der Orientalis vertretenen Arten gehören zu drei Artengruppen. Eine Bestimmungstabelle und ein Katalog werden erstellt. Weitere Nachweise, darunter eine Reihe von Erstnachweisen, werden gemeldet. Die derzeit bekannten Verbreitungsgebiete von zwölf Arten werden anhand von Karten illustriert.

\section{Introduction}

According to Smetana (2004), the lathrobiine genus Pseudolathra CAsey, 1905 is represented in the Palaearctic region by fifteen species in two subgenera, the nominate subgenus and Allolathra Coiffait, 1972. Only four species are listed from the East Palaearctic region; one of them is assigned to Allolathra and the remainder to the nominate subgenus.

An accurate estimate of how many species there are worldwide is currently impossible for several reasons. The vast majority of Pseudolathra species was originally assigned to Lathrobium Gravenhorst, 1802. Currently available evidence suggests that Lathrobium has a Holarctic distribution (Assing in press), so that all the species from other zoogeographic regions that today are attributed to this genus refer to other genera of Lathrobiina, partly also to Pseudolathra. Moreover, Pseudolathra is - and has been - treated as a subgenus of not only of Lathrobium, but also of Lobrathium Mulsant \& Rey, 1878 even by recent authors (e.g., Newton et al. 2001). According to a database compiled by Newton (unpubl.), 33 species of Pseudolathra have been recorded from North America north of Mexico.

Recent and ongoing revisions of the Himalayan Lathrobium species (Assing in press) and of the East Palaearctic representatives of the genus Lobrathium (2012), which included the study of the type material of numerous species originally described in Lathrobium, revealed that two taxa previously assigned to Lobrathium (Lathrobium nigerrimum CAMERON, 1924 and L. regulare SHARP, 1889) in fact belong to Pseudolathra. In order to clarify the status of other Pseudolathra species, further types and additional material previously attributed to this genus were examined. The present paper focuses on the East Palaearctic region sensu SMETANA (2004). Since the distributions of several Pseudolathra species are not confined to the south of the East Palaearctic, the Oriental region is included, too. However, material from these regions is rather poorly represented in the collections examined, so that the current knowledge of the Pseudolathra fauna of the study regions, particularly that of the Oriental region, must be regarded as preliminary. Moreover, several species of "Lathrobium" described from regions like New Guinea (e.g., by LAST 1984) have never been revised and are of uncertain generic affiliations. 


\section{Material, methods, and measurements}

The material referred to in this study is deposited in the following public institutions and private collections:

BMNH

The Natural History Museum, London (R. Booth)

MHNG

Museum d'Histoire Naturelle, Genève (G. Cuccodoro)

MMUM

The Manchester Museum, The Manchester University (D. Logunov)

NHMW

Naturhistorisches Museum Wien (H. Schillhammer)

NME

SDEI

Naturkundemuseum Erfurt (M. Hartmann, assisted by W. Apfel)

SMNS

Senckenberg Deutsches Entomologisches Institut, Müncheberg (L. Behne)

cAss

Staatliches Museum für Naturkunde Stuttgart (W. Schawaller, K. Wolf-Schwenninger)

cKle author's private collection

cSch private collection Andreas Kleeberg, Berlin

private collection Michael Schülke, Berlin

The morphological studies were conducted using a Stemi SV 11 microscope (Zeiss Germany) and a Jenalab compound microscope (Carl Zeiss Jena). A digital camera (Nikon Coolpix 995) was used for the photographs.

Head length was measured from the anterior margin of the frons to the posterior margin of the head, elytral length at the suture from the apex of the scutellum to the posterior margin of the elytra, and the length of the aedeagus from the apex of the dorsal plate or from the apex of protruding internal structures (whichever forms the apex of the aedeagus) to the base of the aedeagal capsule. The „parameral“ side (i.e., the side where the sperm duct enters) is referred to as the ventral, the opposite side as the dorsal aspect.

The limits of the zoogeographic regions are in accordance with the concept used by LöBL \& SMETANA (2004). The maps were created using MapCreator 2.0 (primap) software.

\section{Results}

\section{Diversity and species groups}

In all, thirteen species are recognised in the study region, with ten of them represented in the East Palaearctic (including Middle Asia) and six in the Oriental region. Six species are described for the first time, two new synonymies are proposed, two new combinations are established, and one name is revalidated.

Ten valid species are currently known from the West Palaearctic, at least one of them, P. nehemiahensis Drugmand, 1989, is of doubtful status. The synapomorphically derived morphology of the aedeagus (long, slender and apically acute ventral process) of these species suggests that they form a monophyletic group, which is tentatively attributed to the nominate subgenus. However, the type species of Pseudolathra is Lathrobium anale LeConTe, 1880, a species described from the Nearctic region. Until the male sexual characters of this species have been examined, the subgeneric assignment of the West Palaearctic lineage remains preliminary. If $L$. anale were shown to represent a different lineage, the valid subgeneric name would be Lathrobidium PorTEvin, 1929, which is currently listed as a junior synonym of Pseudolathra.

The East Palaearctic and Oriental species clearly represent a different lineage and are assigned to the subgenus Allolathra Coiffait, 1972, whose type species is P. methneri (Bernhauer, 1911) from the Afrotropical region. Based on the male sexual characters (shape of sternite VIII and 
morphology of the aedeagus), as well as on external characters such as the shape and punctation of the pronotum, the East Palaearctic and Oriental lineage can be subdivided into three species groups.

The $P$. regularis group is represented by only one species, $P$. regularis, and is characterised particularly by the unique shape the male sternite VIII (posterior excision shallow and broad, in all other species deep and very narrow), the intricate morphology of the aedeagus (similar to that of some species of the $P$. nigerrima group), and the slender pronotum.

The P. nigerrima group comprises three species (P. nigerrima, P. transversicollis, P. sagittata), which are distinguished from other species distributed in the study regions by relatively large size, the blackish coloration of the head, pronotum, and abdomen, a distinctly transverse head with very short temples, the weakly oblong or even transverse pronotum, the dorsal series of the pronotum being composed of only few coarse punctures, and by the intricate morphology of the dorso-ventrally somewhat depressed, rather weakly sclerotised aedeagus with a weakly sclerotised dorsal plate. The similarly derived shape and chaetotaxy of the male sternite VII and the similarly derived morphology of the aedeagus suggest that $P$. nigerrima and $P$. transversicollis are adelphotaxa.

The remaining nine species belong to the $P$. unicolor group, which is characterised by relatively small to medium body size, more or less reddish to brownish coloration (often with the head and elytra darker), and a distinctly sclerotised aedeagus with a long, apically projecting, and strongly sclerotised dorsal plate. As can be inferred from the similar general morphology of the aedeagus (structure of dorsal plate and of ventral process), P. unicolor and P. himalayana are probably sister species. The same is probably true of $P$. villiersi and $P$. cordiformis, as is suggested by the similarly derived structure of the dorsal plate (long and slender, almost circular in crosssection).

\section{Natural history}

All the Pseudolathra species of the study region are fully winged and evidently capable of flight, as is suggested by numerous records of light trap catches. The examined material was collected at low to intermediate altitudes. One species was found in a desert. Unlike most Lathrobium and Lobrathium species, Pseudolathra species may be extremely widespread.

The observations that material is relatively rare in the collections examined, that some species have become known only from one or two localities, and that the majority of specimens seems to have been collected with light traps suggest that at least the East Palaearctic and Oriental representatives of the genus reproduce in a cryptic subterranean habitat.

\section{Catalogue of the Pseudolathra species of the East Palaearctic and Oriental regions}

In the references section, only those articles are listed that provide descriptions and/or illustrations of the genitalia. The references are abbreviated as follows: App $=$ present paper; B88 $=$ BонAČ (1988); Ca24 = Cameron (1924); Ca31 = Cameron (1931); Co82a = Coiffait (1982a); Co82b = Coiffait (1982b). 


\begin{tabular}{|c|c|c|}
\hline species & revised distribution & references \\
\hline brevincisa sp. $\mathbf{n}$. & Thailand & App \\
\hline cordiformis sp. $\mathbf{n}$. & SE-India & App \\
\hline himalayana sp. $\mathbf{n}$. & $\begin{array}{l}\text { southern Himalaya from N-Pakistan to } \\
\text { Nepal }\end{array}$ & App \\
\hline $\begin{array}{l}\text { lineata Herman, } 2003 \\
=\text { seriata (SHARP, 1889) }\end{array}$ & Japan, E-China & App \\
\hline nigerrima (CAMERON, 1924), comb. $\mathbf{n}$. & Himalaya: Nepal, N-India & App, Ca24, Ca31 \\
\hline $\begin{array}{l}\text { pulchella (KRAATZ, 1859), revalidated } \\
=\text { caffra javana (CAMERON, 1940), syn. } \mathbf{n} .\end{array}$ & $\begin{array}{l}\begin{array}{l}\text { southern E-Palaearctic and Oriental } \\
\text { regions }\end{array} \\
\end{array}$ & App \\
\hline sagittata sp. $\mathbf{n}$. & Thailand & App \\
\hline regularis (SHARP, 1889), comb. $\mathbf{n}$. & Japan, China & App \\
\hline tichomirovae Вонас̌, 1988 & Tajikistan, Pakistan & B88, App \\
\hline transversicollis sp. $\mathbf{n}$. & N-India (Uttaranchal), Thailand & App \\
\hline $\begin{array}{l}\text { unicolor (KRAATZ, 1859) } \\
=\text { testacea }(\text { MotSCHUlSKY, 1858) } \\
=\text { pallens }(\text { GEMMINGER \& HAROLD, 1868) } \\
=\text { chujoi (LAST, 1966), syn. } \mathbf{n} .\end{array}$ & $\begin{array}{l}\text { Nepal, India, Myanmar, Bangladesh, } \\
\text { China, Thailand }\end{array}$ & App \\
\hline vellicans sp. $\mathbf{n}$. & N-India (Uttaranchal) & App \\
\hline villiersi (CAMERON, 1950) & Sahara; Saudi Arabia; Pakistan & App, Co82a, Co82b \\
\hline
\end{tabular}

\section{Key to species}

1 Coloration of pronotum blackish-brown to blackish, occasionally with the posterior and anterior margin diffusely dark-reddish. 2

Coloration of pronotum reddish-yellow to reddish-brown. Species that can reliably be identified only based on the morphology of the aedeagus.

2 Head oblong (Fig. 65). Pronotum slender, at least approximately 1.2 times as long as broad (Fig. 65). Eyes smaller, much shorter than postocular region in dorsal view (Fig. 65). Punctation of abdomen very dense and fine (Fig. 64); interstices with distinct microsculpture. Length of forebody 3.2-3.9 mm. $\sigma^{*}$ : posterior margin of sternite VIII with shallow and broad posterior excision (Fig. 66); aedeagus shaped as in Figs 67-70. Japan, China (Map 2). ....

\section{P. regularis (SHARP)}

Head distinctly transverse (Fig. 46, 52, 60). Pronotum much broader and relatively shorter, at most very weakly oblong (Fig. 46, 52, 60). Eyes very large at least approximately three times as long as postocular region in dorsal view (Fig. 46, 52, 60). Punctation of abdomen at least on posterior tergites rather sparse; microsculpture absent or indistinct. $\sigma^{7}$ : posterior margin of sternite VIII with narrow and deep posterior incision (Figs 48, 58, 63); aedeagus of different morphology. Distribution different.

3 Conspicuously large species; body length 9.0-10.5 mm; length of forebody at least $4.5 \mathrm{~mm}$. Elytra reddish to reddish-brown, posteriorly often diffusely infuscate. All abdominal tergites with reddish lateral and posterior margins. Pronotum usually weakly transverse (Fig. 52). $\sigma^{*}$ : sternites VII with broadly concave posterior margin, in median posterior portion without setae (Fig. 57); sternite VIII as in Fig. 58; aedeagus large, 1.4-1.5 mm long, shaped as in Figs 53-56. N-India, Thailand (Map 3).

P. transversicollis $\mathrm{sp} . \mathrm{n}$. 
Smaller species; length of forebody $<4.5 \mathrm{~mm}$. Elytra and abdomen black. Pronotum at most approximately as broad as long. $\sigma^{*}$ : sternite VII of different shape and chaetotaxy; aedeagus smaller and of different shape. 4

4 Larger species; body length 7.0-9.5 mm; length of forebody 4.0-4.4 mm. Legs at least yellowish-brown. Anterior abdominal tergites with finer punctation. $0^{7}$ : sternite VII of distinctive shape and chaetotaxy (Fig. 47); sternite VIII as in Fig. 48; aedeagus broad in ventral view, shaped as in Figs 49-51; ventral process apically not bifid. Southern Himalaya (N-India, Nepal) (Map 2).

P. nigerrima (CAMERON)

- Smaller species; body length 6.5-7.5 mm; length of forebody 3.5-4.0 mm. Legs yellowish. Anterior abdominal tergites with coarse and dense punctation. $\sigma^{*}$ : sternites VII without distinct modifications; sternite VIII as in Fig. 63; aedeagus slender, with apically bifid ventral process and with arrow-shaped apex of the dorsal plate (Figs 61-62. Thailand. ....

P. sagittata sp. n.

5 Slightly larger species; length of forebody $>3.0 \mathrm{~mm}$. Head mostly blackish, distinctly contrasting with the reddish pronotum.

6

Slightly smaller species; length of forebody $<3.1 \mathrm{~mm}$. Head usually reddish or brown, more rarely blackish. . .7

6 Dorsal surface of head less sparsely punctate; punctate portion near posterior margin not confined to very narrow transverse band near neck. Antennae longer (2.0-2.4 mm) and more massive. $0^{*}$ : sternite VIII as in Fig. 39; aedeagus as in Figs 33-34. Widespread in the southern East-Palaearctic and Oriental regions (Map 3). P. pulchella (KRAATZ)

Dorsal surface with practically impunctate median portion; punctate portion near posterior margin confined to very narrow transverse band near neck. Antennae approximately $2.0 \mathrm{~mm}$ long and fine. $0^{\mathbf{T}}$ : sternite VIII as in Fig. 40; aedeagus compicuously large in relation to body size, with dagger-shaped (lateral view), apically bifid (ventral view) ventral process, and with conspicuous pair of apical structures of clawlike shape (Figs 41-44). N-India: Uttaranchal (Map 3).

P. vellicans sp. $\mathrm{n}$.

$\sigma^{\star}$ : aedeagus with bilobed dorsal plate and with ventral process of distinctive shape (BoHAČ 1988: figures 14-15). Tajikistan, Pakistan (Map 1). P. tichomirovae BОHAС̆ $\sigma^{\star}$ : aedeagus with completely differently shaped dorsal plate and ventral process. ......... 8

$\sigma^{*}$ : dorsal plate of aedeagus slender and long, sometimes almost circular in cross-section, gently curved in lateral view. 11

$\sigma^{\star}$ : posterior incision of sternite VIII shorter, approximately one third the length of sternite (Fig. 21); aedeagus small, $0.75 \mathrm{~mm}$ long and of distinctive shape (Figs 22-24). Thailand (Map 1). P. brevincisa sp. $\mathrm{n}$.

$\sigma^{\star}$ : posterior incision deeper, almost reaching half the length of sternite; aedeagus larger, at least $1.0 \mathrm{~mm}$ long. 10

$10 \quad 0^{*}$ : aedeagus longer, 1.15-1.30 mm long, and with longer dorsal plate (Figs 1-8); sternite VIII as in Fig. 10. Widespread (Map 1). P. unicolor (KRAATZ) $\sigma^{\star}$ : aedeagus shorter, $1.0-1.1 \mathrm{~mm}$ long, and with shorter, apically more rounded (ventral view) dorsal plate (Figs 13-14); sternite VIII as in Fig. 12. SW-Himalaya from N-Pakistan to Nepal (Map 2). P. himalayana sp. $\mathrm{n}$. 
$110^{*}$ : aedeagus with dorsal plate apically cordiform in ventral view (Figs 31-32). SE-India (Map 1). P. cordiformis sp. n.

- $\quad \sigma^{\star}$ : aedeagus with dorsal plate apically acute in ventral view. 12

12 Elytra uniformly reddish. o $^{\star}$ : aedeagus as in Figs 27-28. Widespread from the Sahara to Pakistan. P. villiersi (CAMERON)

Elytra infuscate in postero-lateral portion. $\sigma^{\star}$ : aedeagus as in Figs 18-19. Japan, E-China (Map 1). P. lineata HERMAN

\section{Species descriptions and additional records}

\section{Pseudolathra unicolor (KraATZ, 1859) (Figs 1-10, Map 1)}

Lathrobium unicolor KRAATZ, 1859: 117.

Lathrobium testaceum MoTSCHULSKY, 1858: 646 f.; preoccupied.

Lathrobium pallens GeMminger \& Harold, 1868: 611; replacement name.

Lathrobium chujoi LAST, 1966: 5 f.; syn. n.

Type material examined:

L. unicolor: Lectotype $0^{\star}$ [dissected prior to present study; somewhat damaged], present designation: "India orient. / Coll. Kraatz / Coll. DEI Eberswalde / Syntypus / Pseudolathra unicolor (Kr.) o*, V.I. Gusarov det. 1994 / DEI Müncheberg, Col - 02775 / Lectotypus ơ Lathrobium unicolor Kraatz, desig. V. Assing 2012 / Pseudolathra unicolor (Kraatz), det. V. Assing 2012” (SDEI). Paralectotypes: 2 ㅇ ㅇ: same data as lectotype (SDEI); 1 ㅇ: same data, but "India or., Bacon leg." (SDEI).

L. chujoi: Paratypes: 1 o, 2 exs. : "Manchester Museum Paratype / F8008.5327-29 / Lathrobium chûjôi sp. n., Paratype, H. Last det. / Pseudolathra unicolor (Kraatz), det. V. Assing 2012” (MMUM).

\section{Comment:}

The - extremely short - original description of Lathrobium unicolor is based on an unspecified number of syntypes from "India orientale, praecipue boreali" collected by "Dom. Bacon" (KrAATZ 1859). Four syntypes, one male and three females, were located in the Kraatz collection at the SDEI. They had lectotype and paralectotype labels by V. Gusarov attached to them, but since a lectotype designation had not been published, these labels were removed to avoid confusion. The male is here designated as the lectotype; its aedeagus is illustrated in Figs 1-2.

Lathrobium testaceum was described from an unspecified number of syntypes from "Indes orientales" (Mотschulsky 1858). This name is a junior primary homonym and was subsequently replaced with L. pallens by GeMminger \& HAROLD (1868). Lathrobium pallens and L. testaceum have been treated as synonyms of L. unicolor at least since FAUvel (1904).

In the original description of $L$. chujoi, which is based on a "Type, $q$ " [sic] and eleven paratypes from "Thailand: Nakon Sawan (LAST 1966), there is no reference whatsoever to Pseudolathra unicolor. An examination of three paratypes revealed that they are conspecific with P. unicolor, hence the synonymy proposed above. The aedeagus of a male paratype is illustrated in Figs 5-6.

Additional material examined:

Nepal: 7 exs., Narayani, Chitwan, Gynganagar, at light, 9.V.2005, leg. Ahrens (NME, cAss); 1 ㅇ, Chitwan National Park, Sauraha, ca. 200 m, at MV light, 4.VI.1983, leg. Brendell (BMNH). 
India: 13 exs., Assam, Kaziranga Wildlife, Pan Bari Reserve Forest, 264ㄴ' N, 93ํ10'E, 100 m, 12-21.XI.1997, leg. Siniaev \& Murzin (cSch, cAss); 4 우 옹. Assam, Bhalukpong, $27^{\circ} 02^{\prime} \mathrm{N}, 92^{\circ} 35^{\prime} \mathrm{E}, 150 \mathrm{~m}, 26 . \mathrm{V} .-3 . \mathrm{VI} .2006$, leg. Dembický \& Pacholátko (BMNH, cAss); $10^{\top}$, Assam, Umrongso env., 2527' N, 92 $43^{\circ} \mathrm{E}, 700 \mathrm{~m}$, 3-8.VI.2002, leg. Trýzna \& Benda (cSch); 1 ㅇ, West Bengal, Darjeeling distr., Kalimpong, Dumra Busty, 1000 m, 12.VIII.1990, leg. Dangal (cKle); 1 ㅇ, 2 exs. without abdomen, Calcutta (BMNH); 1 ㅇ, Calcutta, 26.X.1949, leg. Kapur (BMNH); 1 ㅇ, Arunachal Pradesh, 8 km S Jamiri, near Sessa, 2707-09'N, 92³4'E,

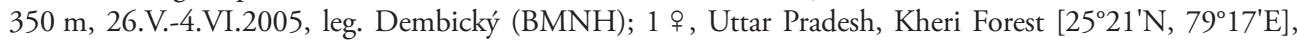

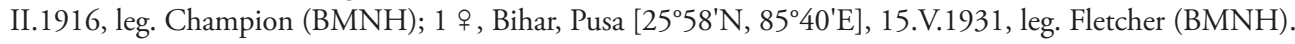
Myanmar: 5 exs., Pegu, 60 km NW Yangon, $17^{\circ} 19^{\prime} \mathrm{N}, 96^{\circ} 28^{\prime} \mathrm{E}$, light trap, 22.XI.2003, leg. Hornburg (cSch, cAss); $10^{\star}, 2$ ㅇ ㅇ, Tharrawaddy, leg. Corbett, Andrewes, etc. (BMNH); 1 ㅇ, locality not specified (BMNH).

Bangladesh: $10^{*}$, Dhaka ["Dacca”] (BMNH).

China: 1 ex., Yunnan, Dali Bai Aut. Pref., 5 km SSW Dacang, water reservoir, $25^{\circ} 24^{\prime} \mathrm{N}, 100^{\circ} 12^{\prime} \mathrm{E}, 1780 \mathrm{~m}$, bank of reservoir, 17.IX.2009, leg. Wrase (cAss).

Thailand: 1 \% $25 \mathrm{~km}$ NW Lan Sak, X.1989, leg. Thielen (cAss); 2 우, Kanchanaburi, farmland near Kwai river, 400 m, 25.-27.III.1987, leg. Brendell (BMNH). Locality not identified: 1 \%, Shuregu [?], leg. Champion (BMNH).

\section{Redescription:}

Body length 5-6 mm; length of forebody 2.7-3.0 mm. Coloration variable: body either uniformly reddish or partly (head, postero-lateral portion of elytra, abdominal segments III-VI) more or less distinctly infuscate; legs yellowish to reddish-yellow; antennae reddish.

Head approximately as broad as long or weakly transverse; punctation coarse and sparse, in median dorsal portion very sparse or absent; interstices without microsculpture and glossy. Eyes large, but of variable size, usually somewhat longer, rarely shorter than postocular region in dorsal view. Antennae slender, 1.8-2.0 mm long; all antennomeres oblong.

Pronotum of somewhat variable shape, 1.1-1.2 times as long as broad and approximately 1.1 times as broad as head; on either side of the impunctate midline with series of 15-20 punctures, these punctures often accompanied by additional punctures; punctation of lateral portions sparse to moderately dense; interstices without microsculpture.

Elytra approximately as long as pronotum or slightly longer; laterally with fine and almost complete submarginal carina; punctation arranged in more or less pronounced series; interstices without microsculpture. Hind wings fully developed.

Abdomen slightly narrower than elytra; punctation very fine and very dense; interstices with microsculpture; posterior margin of tergite VII with palisade fringe.

$\sigma^{\star}$ : protarsomeres I-IV strongly dilated; sternite VII without distinctly modified pubescence and shallow median impression, posterior margin broadly concave (Fig. 9); sternite VIII oblong, posterior excision narrow and deep, not quite reaching middle of sternite (Fig. 10); aedeagus 1.15-1.30 mm long, shaped as in Figs 1-8.

+ : protarsomeres I-IV distinctly dilated, but slightly less so than in male.

\section{Intraspecific variation:}

This species is highly variable, particularly in coloration, density of punctation, eye size, shape of head and pronotum, to some extent also in the size of the aedeagus. In material from India, the body is usually of uniformly reddish coloration, whereas in specimens seen from Myanmar and China the head and the postero-lateral portion of the elytra are often more or less distinctly infuscate; occasionally the head may even be black. In most specimens the eyes are large, bulging, and longer than the postocular region; in the male from China, however, they are less convex and shorter than the postocular region. The variation of the aedeagus is illustrated in Figs 1-8. 

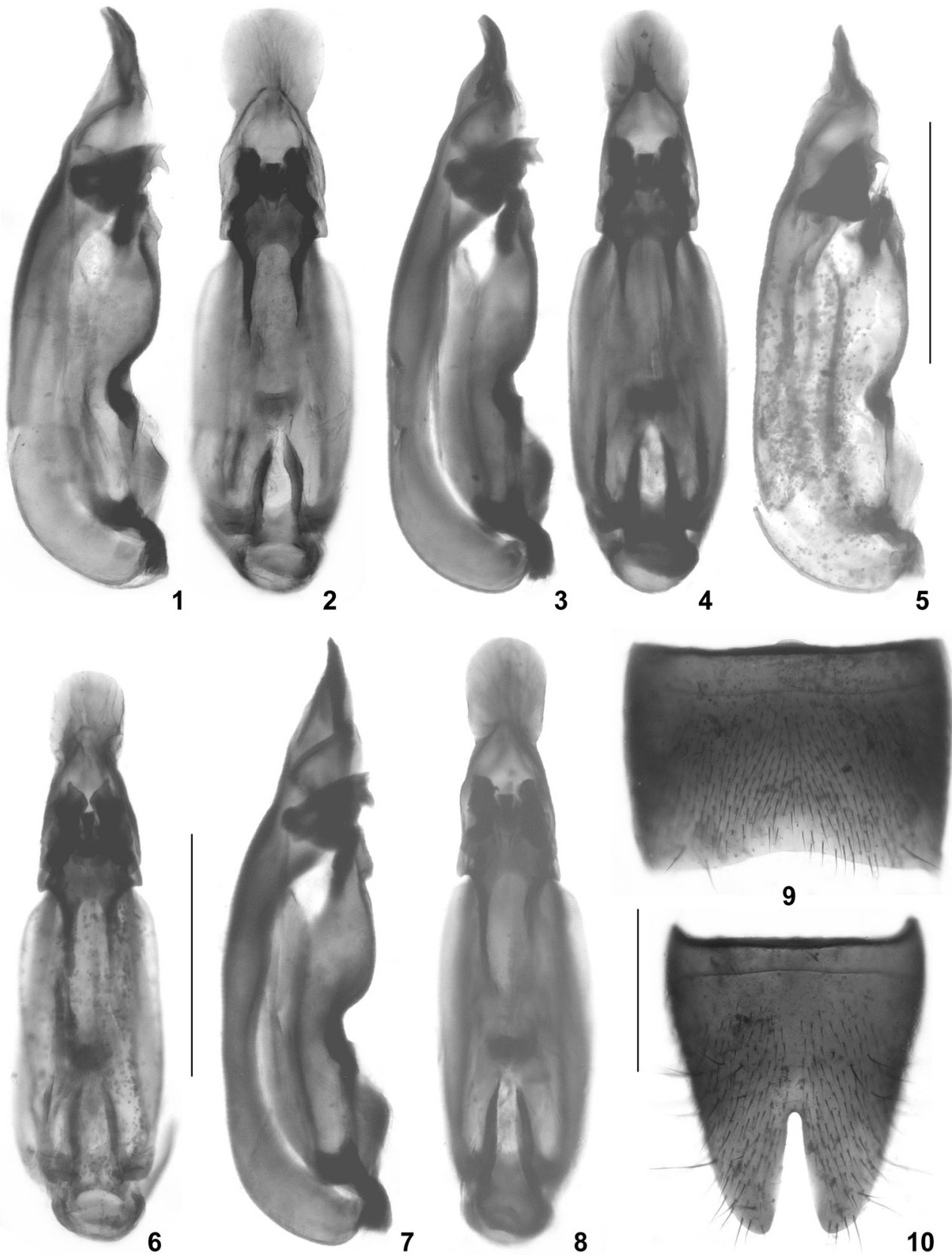

9

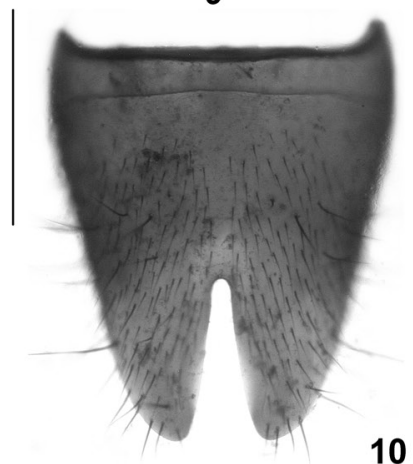

Figs 1-10: Pseudolathra unicolor; lectotype of P. unicolor (1-2), paratype of P. chujoi (5-6), and males from Assam (3-4) and Yunnan (7-10): aedeagus in lateral and in ventral view (1-8); male sternite VII (9); male sternite VIII (10). Scale bars: $0.5 \mathrm{~mm}$. 


\section{Distribution and natural history:}

The species is evidently widespread in the southern East Palaearctic and Oriental regions. Malebased records have been seen from Nepal, North India, Myanmar, Bangladesh, China, and Thailand (Map 1). Owing to possible confusion with externally similar species (P. himalayana, P. villiersi, etc.), all previous records and all the female-based records listed above should be considered doubtful.

On at least two occasions, $P$. unicolor was collected at light traps in May and November. In one locality in southern central Nepal, the species was found together with P. himalayana and P. pulchella. One specimen from China was taken on the shore of a reservoir.

Pseudolathra bimalayana sp. n. (Figs11-14, Map 2)

\section{Type material:}

Holotype ơ: "Nepal, Narayani, Chitawan, Gynganagar, 09.V.2005 LF, leg. D. Ahrens / Holotypus $\sigma^{\star}$ Pseudolathra himalayana sp. n., det. V. Assing 2012" (NME). Paratypes: $3 \sigma^{\star} \sigma^{\star}, 2$ ㅇ ㅇ : same data as holotype (NME, cAss); 4 exs.: "Nepal, Chitawan National Park, at MV light, Sauraha, 700', 3.-6.VI.1983, leg. Brendell” (BMNH); 2 exs.: same data, but 4.VI.1983 (BMNH); 2 o $^{\star}$, 4 exs.: "632 Nepal: Kathmandu, Baneshwar, 1350 m, 18.-24.VI.2000, leg. W. Schawaller" (cAss); 1 o`: “Nepal: 4500', Kathmandu, British Embassy, 20.v.-23.vi.1983 / At light / M.J.D. Brendell, B.M. 1983-222” (SMNS, cAss); 1 ex., same data, but “600 ... 20.-21.V.2000” (SMNS); 2 o` ơ, 2 ㅇ 우:

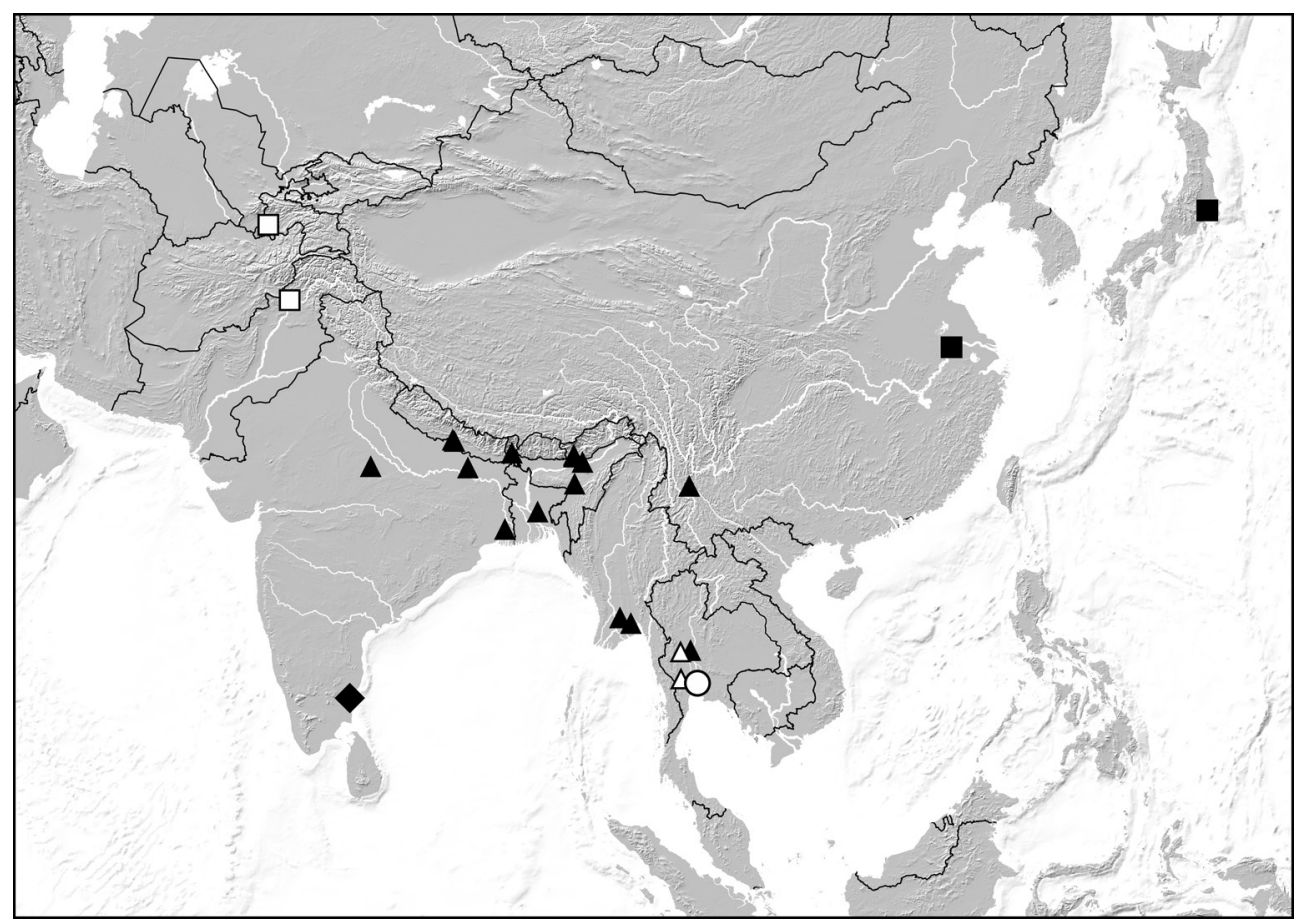

Map 1: Distributions of Pseudolathra unicolor (triangles; open triangles: female-based records), P. tichomirovae (open squares), P. lineata (filled squares), P. cordiformis (filled diamond), and P. brevincisa (open circle), based on revised records. 


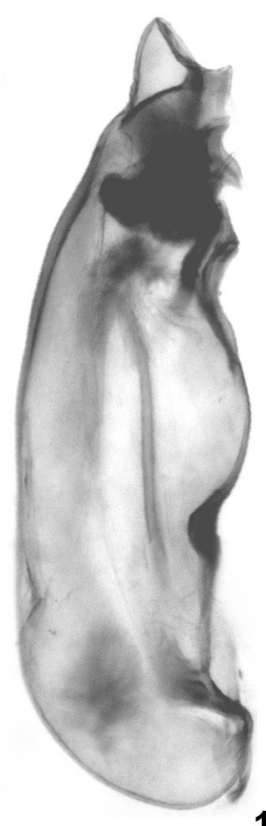

13

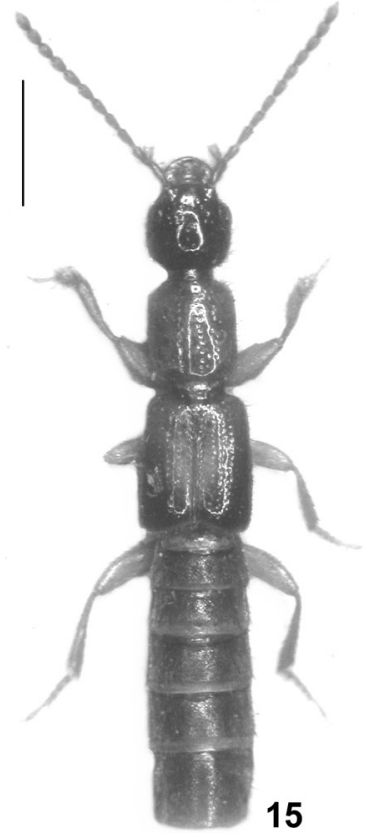

14

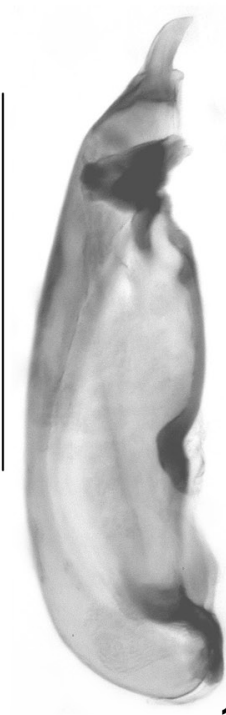

18

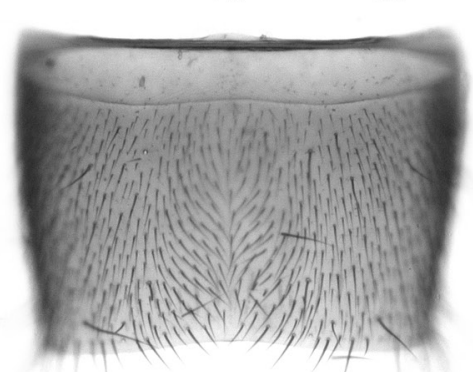

11
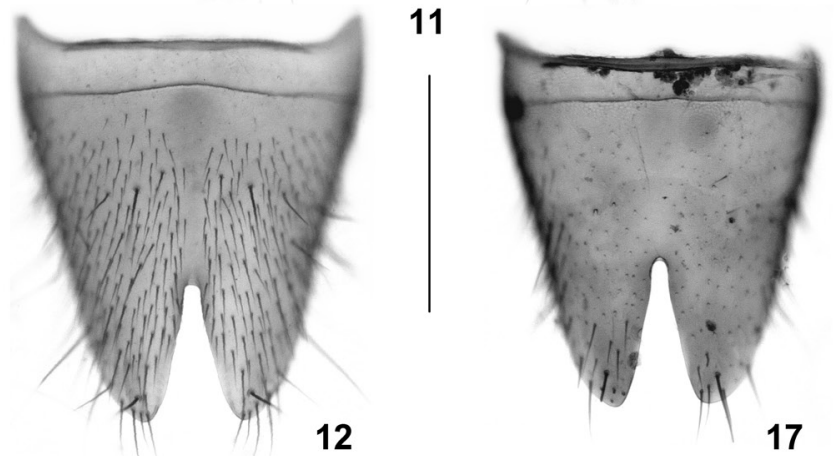

16

Figs 11-19: Pseudolathra himalayana (11-14) and P. lineata, lectotype (15-19): male sternite VII (11); male sternite VIII $(12,17)$; aedeagus in lateral and in ventral view $(13-14,18-19)$; habitus $(15)$; forebody $(16)$. Scale bars: 15-16: $1.0 \mathrm{~mm}$; 11-14, 17-19: 0.5 mm. 
"Pakistan, Northwest Frontier Province, Khyber agency, middle stream of Kabul river, 15.-22. VIII.2005, 700-900 m, leg. V. Gurko" (cSch, cAss); 1 : "Pakistan: Northwest Frontier Province: South Waziristan agency, near Tanai village / 28.VII.-12.VIII.2005, 1500-2500 m, leg. V. Gurko" (cSch); 1 ㅇ: "Pakistan: Azad, Jammu \& Kashmir, SW Garhi, 1500 m, 10.-20.VII.2003" (cAss); 14 exs.: "Pakistan, N.W.F.P., $7 \mathrm{~km}$ SE Peshawar, ca. $33^{\circ} 58^{\prime} \mathrm{N}, 71^{\circ} 40^{\prime} \mathrm{E}$, arable land, at light, 14.VII.2011, leg. Zubair" (cAss); $10^{\star}:$ "Sarda [= Sarda river in Uttar Pradesh; approx. $27^{\circ} 21^{\prime} \mathrm{N}$, $81^{\circ} 23^{\prime} \mathrm{E}$; altitude approx. $300 \mathrm{~m}$ ], Bengal, F. W. C. / Lathrobium unicolor / Aedeagus at rest turned to $180^{\circ}$ in abdomen / Pseudolathra sp. $20^{\star} \sigma^{\star}$, V.I. Gusarov det. 1992 / G.C. Champion coll. B.M. 1927-409” (BMNH); 2 우 ㅇ: “Sarda, Bengal, F. W. C. / Pseudolathra sp. 2 우 우, V.I. Gusarov det. 1992 / G.C. Champion coll. B.M. 1927-409" (BMNH); 1 o: "Haldwani Divn. Kumaon, U.P., Jne '23. H.G.C. / at light / 3997 / G.C. Champion coll. B.M. 1927-409” (BMNH).

\section{Etymology:}

The specific epithet is an adjective derived from Himalaya.

\section{Description:}

Body length 5-6 mm; length of forebody $2.7-3.0 \mathrm{~mm}$. Coloration variable: body uniformly reddish or partly (head, posterior portion of elytra, abdominal segments III-VI) more or less distinctly infuscate; legs yellowish to pale reddish; antennae reddish. Of similar external appearance and as variable as $P$. unicolor; reliably distinguished only by the male sexual characters.

$\sigma^{*}$ : sternite VII in the middle with rather extensive impression, setae in this impression directed obliquely postero-mediad, posterior margin very weakly concave (Fig. 11); sternite VIII of similar shape as in P. unicolor, but midline without setae (Fig. 12); aedeagus 1.0-1.1 mm long, shaped as in Figs 13-14.

\section{Comparative notes:}

As can be inferred from the similar external morphology and particularly by the similar male sexual characters (shape and chaetotaxy of sternite VIII; general morphology of the aedeagus), $P$. himalayana is closely allied to and probably the adelphotaxon of $P$. unicolor, with which it was previously confounded. It is distinguished from $P$. unicolor especially by the differently shaped (both in lateral and in ventral view) and smaller aedeagus.

\section{Distribution and natural history:}

The currently known distribution ranges across the West Himalaya from northern Pakistan to central Nepal and northern India (Map 2). The specimens were collected at altitudes between 700 and at least $1500 \mathrm{~m}$. Numerous beetles were collected at light sources in May and June. In one locality in southern central Nepal, the species was collected together with P. unicolor and P. pulchella.

\section{Pseudolathra lineata Herman, 2003 (Figs 15-19, Map 1)}

Lathrobium seriatum SHARP 1889: 259; preoccupied.

Pseudolathra lineata Herman 2003: 7; replacent name.

Type material examined:

Lectotype $\sigma^{\star}$ [dissected prior to present study], present designation: "Lathrobium seriatum. Type D.S. Yokohama, Lewis [written on mounting label] / Japan. G. Lewis. / Type / Sharp Coll 1905-

313. / Aedeagus at rest turned to $180^{\circ}$ in abdomen / Pseudolathra seriata (Sharp) o ${ }^{*}$, V.I. Gusarov 
det. 1992 / Lectotypus ơ Lathrobium seriatum Sharp, desig. V. Assing 2012 / Pseudolathra lineata Herman, det. V. Assing 2012" (BMNH).

Additional material examined:

China: $3{\sigma^{\star}}^{\star}$, Jiangsu, Nanjing, Agricultural University, VII.1991, leg. Cooter (MMUM, cAss).

\section{Comment:}

The original description of L. seriatum is based on "two examples" from "Yokohama" (SharP 1889). The name is a junior primary homonym and was replaced with the nomen novum Pseudolathra lineata by Herman (2003). The above type specimen, a male in good condition, is designated as the lectotype.

\section{Redescription:}

Body length 4.9-5.8 mm; length of forebody 2.9-3.1 mm. Habitus as in Fig. 15. Coloration: head blackish-brown; pronotum and elytra reddish, with the postero-lateral portion of the elytra more or less extensively infuscate; abdomen dark-reddish; legs and antennae reddishyellow.

Head (Fig. 16) approximately as broad as long; punctation coarse and sparse, in median dorsal portion very sparse; interstices without microsculpture, but with micropunctation, and glossy. Eyes large, longer than postocular region in dorsal view. Antennae slender, $1.9 \mathrm{~mm}$ long; all antennomeres oblong.

Pronotum (Fig. 16) approximately 1.15 times as long as broad and approximately 1.05 times as broad as head; on either side of the impunctate midline with series of approximately 15 punctures, these punctures partly accompanied by additional punctures; punctation of lateral portions unevenly distributed; interstices without microsculpture.

Elytra (Fig. 16) 1.0-1.1 times as long as pronotum; laterally with fine submarginal carina; punctation moderately coarse, arranged in several series; interstices without microsculpture. Hind wings fully developed.

Abdomen distinctly narrower than elytra; punctation very fine and dense; interstices with microsculpture; posterior margin of tergite VII with palisade fringe.

$\sigma^{*}$ : protarsomeres I-IV strongly dilated; sternite VII with almost truncate posterior margin, pubescence unmodified; sternite VIII oblong, posterior excision narrow and deep, almost reaching middle of sternite (Fig. 17); aedeagus 0.9 mm long, shaped as in Figs 18-19.

क: not available.

\section{Distribution:}

Pseudolathra lineata was previously known only from Japan. The above specimens from Jiangsu (Map 1) represent the first record from China. They were collected in the same locality as P. regularis.

Pseudolathra brevincisa sp. n. (Figs 20-24, Map 1)

\section{Type material:}

Holotype ơ: "151 / Bangkok / inconnue / Lathrobium n.s. Bangkok / Sharp Coll 1905-313 / Holotypus ơ Pseudolathra brevincisa sp. n., det. V. Assing 2012” (BMNH). 


\section{Etymology:}

The specific epithet is composed of the Latin adjectives brevis (short) and incisa (incised), and refers to the shape of the posterior incision of the male sternite VIII, one of the characters distinguishing this species from the similar P. unicolor.

\section{Description:}

Body length $4.7 \mathrm{~mm}$; length of forebody $2.7 \mathrm{~mm}$. Coloration: head dark-brown; remainder of body reddish; legs yellowish; antennae reddish yellow.

In external characters highly similar to $P$. unicolor (Fig. 20) reliably distinguished only by the male primary and secondary sexual characters:

$\sigma^{7}$ : sternite VII not distinctly modified; sternite VIII oblong, posterior incision moderately deep, its depth little more than one third of length of sternite (Fig. 21); aedeagus small, $0.75 \mathrm{~mm}$ long and of very distinctive shape (Figs 22-23), ventral process apically bifid (Fig. 24).

\section{Comparative notes:}

This species is reliably distinguished from L. unicolor, L. himalayana, and other similar species only by the morphology of the aedeagus and the relatively short posterior excision of the male sternite VIII.

\section{Distribution:}

Pseudolathra brevincisa is currently known only from the type locality in Thailand (Map 1).

\section{Pseudolathra villiersi (CAMERON, 1950) (Figs 25-28)}

Lathrobium villiersi CAMERON, 1950: $213 \mathrm{f}$.

\section{Type material examined:}

Paratype ㅇ: "Paratype / Agadez, Aïr Sud, 525 m, 8.VIII / IFAN 1947, L. Chopard, A. Villiers / Lathrobium villiersi Cam. P. Type / M. Cameron Bequest B.M. 1955-147. / Pseudolathra villiersi (Cameron), det. V. Assing 2012” (BMNH).

\section{Comment:}

The original description of Lathrobium villiersi is based on a "Type à l'Ifan" from "Monts Tarraouaji (900 m.)" (CAMERon 1950) in the Air range in Niger. The aedeagus of the holotype was figured by CoIfFait (1982b).

Additional material examined:

Pakistan: 2 o $^{\text {t }}$ [1 slightly teneral], Baluchistan, Zhob valley, sand desert, 24.-25.VIII.2009, leg. Gurko (cSch, cAss); 4 우 우, Tribal Area, Sulaiman mts., Drazinda tribal agency, 1700 m, 17.-21.VIII.2008, leg. Gurko (cSch, cAss).

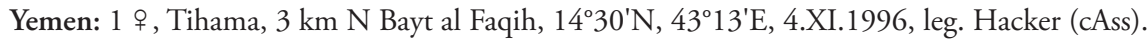

\section{Diagnosis:}

In external characters highly similar to $P$. unicolor and $P$. himalayana; reliably distinguished only by the male primary and secondary sexual characters:

$\sigma^{*}$ : sternite VII without distinctly modified pubescence, posterior margin almost truncate (Fig. 25); sternite VIII of similar shape and chaetotaxy as in P. unicolor (Fig. 26); aedeagus approximately $1.0 \mathrm{~mm}$ long, dorsal plate with slender and apically acute (ventral view) apical portion of distinctive shape (Figs 27-28). 
Beitr. Ent. 62 (2012) 2
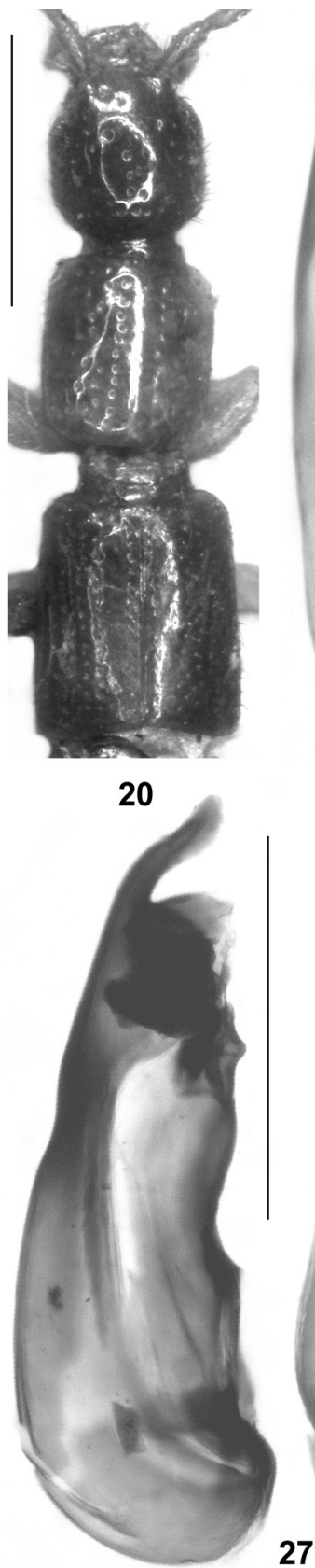

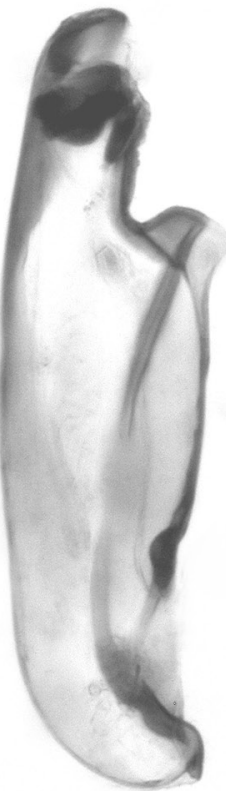

22

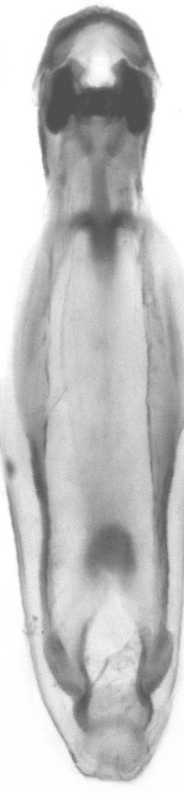

23
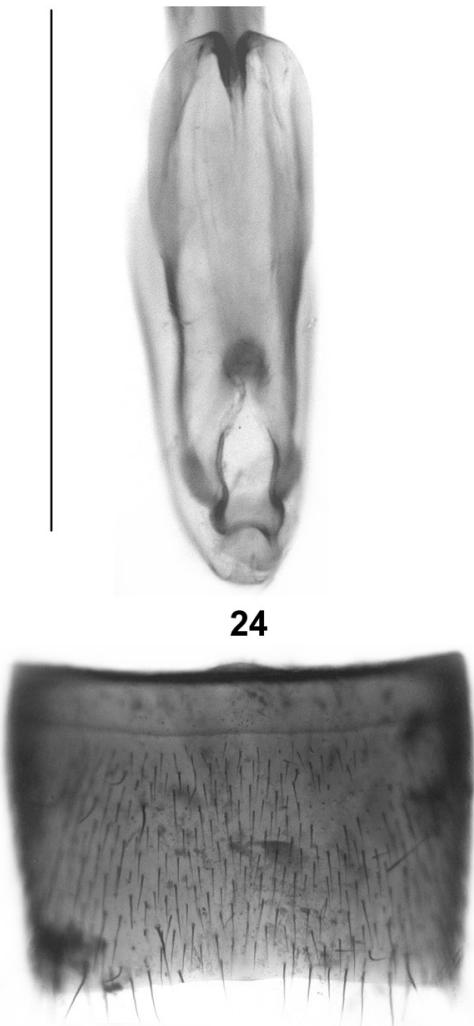

25

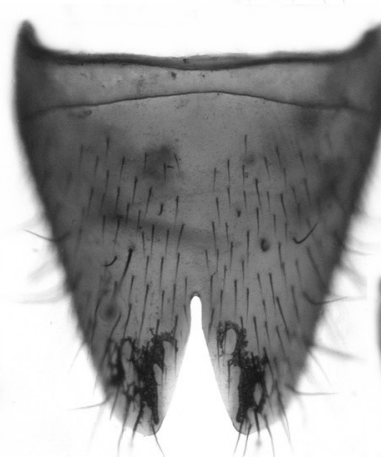

26

Figs 20-28: Pseudolathra brevincisa (20-24) and P. villiersi from Pakistan (25-28): forebody (20); male sternite VIII $(21,26)$; aedeagus in lateral and in ventral view $(22-23,27-28)$; ventral process of aedeagus in ventral view (24); male sternite VII (25). Scale bars: 20: $1.0 \mathrm{~mm}$; 21-28: $0.5 \mathrm{~mm}$. 


\section{Distribution and natural history:}

Pseudolathra villiersi was previously known from the Sahara and Saudi Arabia (CoIffait 1982a, 1982b). The above specimens from Pakistan represent a new country record and considerably expand the known distribution eastwards. The female-based record from Yemen is tentative and requires confirmation. The species appears to be adapted to arid habitats. One specimen collected in August is slightly teneral.

Pseudolathra cordiformis sp. n. (Figs 29-32, Map 1)

\section{Type material:}

Holotype $\sigma^{*}$ [slightly damaged: most of left antenna, right protarsi, mesotarsi, and most of right hind leg missing]: "India/Tamil Nadu, Mettukuppam by Neyveli (Cudalore), 5.I.-1.III.2008, leg. F. Burger Lux / Holotypus ơ Pseudolathra cordiformis sp. n., det. V. Assing 2012” (NME).

\section{Etymology:}

The specific epithet (Latin, adjective: heart-shaped) alludes to the shape of the dorsal plate of the aedeagus.

\section{Description:}

Body length $5 \mathrm{~mm}$; length of forebody $2.7 \mathrm{~mm}$. Coloration: head blackish-brown; pronotum and elytra reddish; abdomen reddish, with segments III-VI slightly darker; legs and antennae reddish-yellow.

Head approximately as long as broad, tapering behind eyes; posterior angles weakly marked; punctation coarse and sparse. Eyes bulging, slighly longer than postocular region in dorsal view. Antennae $1.8 \mathrm{~mm}$ long.

Pronotum 1.15 times as long as broad and 1.1 times as broad as head; dorsal series composed of approximately 15 punctures and some additional punctures; lateral portions with sparse punctation.

Elytra nearly as long as pronotum; punctation arranged in straight series. Hind wings fully developed.

Abdomen narrower than elytra; punctation dense and fine; interstices with microsculpture; posterior margin of tergite VII with palisade fringe.

$0^{\text {t: }}$ protarsomeres I-IV strongly dilated; sternite VII with weakly concave posterior margin, pubescence unmodified (Fig. 29); sternite VIII oblong, posterior excision narrow and deep, its depth nearly $2 / 5$ the length of sternite (Fig. 30); aedeagus $1.0 \mathrm{~mm}$ long, similar to that of $P$. villiersi, but apex of dorsal plate somewhat heart-shaped in ventral view (Figs 31-32).

\section{Comparative notes:}

The similarly derived morphology of the aedeagus suggests that $P$. cordiformis is closely allied to P. villiersi. Both species are reliably distinguished only by the shape of the aedeagus, particularly that of the apex of the dorsal plate.

\section{Distribution and natural history:}

The type locality is situated in Tamil Nadu, near Cuddalore, in southeastern India (Map 1). The holotype was collected with a light trap. 


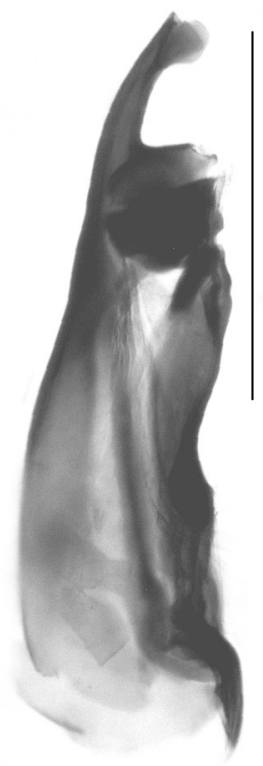

31

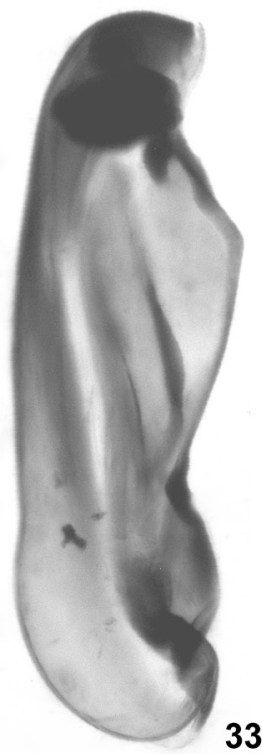

Figs 29-37: Pseudolathra cordiformis (29-30), P. pulchella from Malaysia (33-34), and P. caffra from Kenya (35-37): male sternite VII (29); male sternite VIII (30); aedeagus in lateral and in ventral view (31-36); ventral process of aedeagus in ventral view (37). Scale bars: $0.5 \mathrm{~mm}$. 
Pseudolathra tichomirovae ВоНАС̆, 1988 (Map 1)

Pseudolathra (Allolathra) tichomirovae BонАс̌, 1988: 438 f.

\section{Comment:}

The original description is based on a male holotype and a female paratype from "Kyzil Kala by Kurga Tube" in Tajikistan (BонAč 1988).

\section{Material examined:}

Pakistan: $10^{\star}, 1$ ㅇ, Pakistan, N.W.F.P., $7 \mathrm{~km}$ SE Peshawar, ca. 335' $\mathrm{N} 71^{\circ} 40^{\prime} \mathrm{E}$, arable land, at light, 14.VII.2011, leg. Zubair (cAss).

\section{Diagnosis:}

In external characters highly similar to $P$. unicolor and $P$. himalayana, but on average slightly larger and of darker coloration (head blackish-brown to blackish); reliably distinguished only by the male primary and secondary sexual characters. The distinctive aedeagus is illustrated by BонAČ (1988).

\section{Distribution and natural history:}

This species was originally described from Tajikistan. The examined specimens represent the first record since the original description and a new country record from Pakistan (Map 1). They were collected with a light trap, together with 14 specimens of $P$. himalayana.

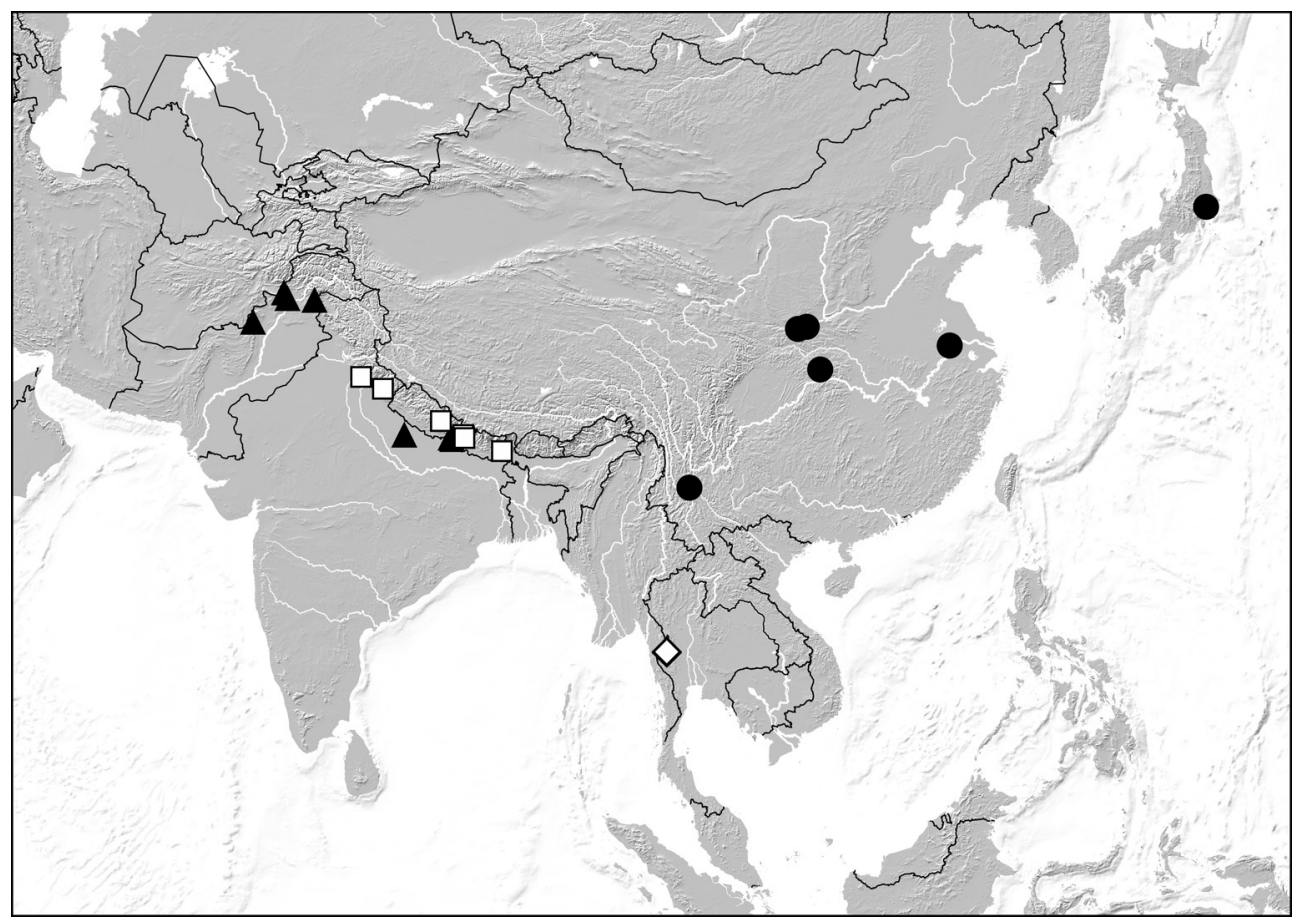

Map 2: Distributions of Pseudolathra himalayana (filled triangles), P. nigerrima (open squares), P. sagittata (open diamond), and $P$. regularis (filled circles), based on revised records. 
Beitr. Ent. 62 (2012) 2

Pseudolathra pulchella (KRAATZ, 1859), revalidated (Figs 33-34, 38-39, Map 3)

Lathrobium pulchellum KRAATZ, 1859: 116; revalidated.

Lathrobium cafrum [sic] javanum CAMERON, 1940: 104; syn. n.

Type material examined:

L. pulchellum: Syntypes: 3 ㅇ : "Ceylon / Syntypus / Coll. Kraatz / Coll. DEI Eberswalde / Paralectotypus o Lathrobium pulchellum Kraatz, V. Gusarov des. 1993 / Pseudolathra pulchella (Kr.) ㅇ , V.I. Gusarov det. 1994 / DEI Müncheberg, Col - 02772-02774 / Pseudolathra pulchella (Kraatz), det. V. Assing 2012" (SDEI); 1 : same data, but "Lectotypus $ᄋ$ Lathrobium pulchellum Kraatz, V. Gusarov des. 1993" and additional labels "145" and "Lathrobium pulchellum Kr." (SDEI).

L. caffrum javanum: Syntype + : “Tjilatjap, Java, Drescher, 14.II.1926 / L. cafrum s. sp. javanum Cam. / Syntype / Pseudolathra pulchella (Kraatz), det. V. Assing 2012” (BMNH).

\section{Comment:}

Lathrobium pulchellum was described from an unspecified number of syntypes from "Ceylan" (KraAtz 1859). Four type specimens were located in the collections of the SDEI. They have (para-)lectotype labels by V. Gusarov attached to them, but a designation was never published. In view of the fact that all the available type specimens are females and probably conspecific, a lectotype designation does not seem advisable. Lathrobium pulchellum was synonymised with

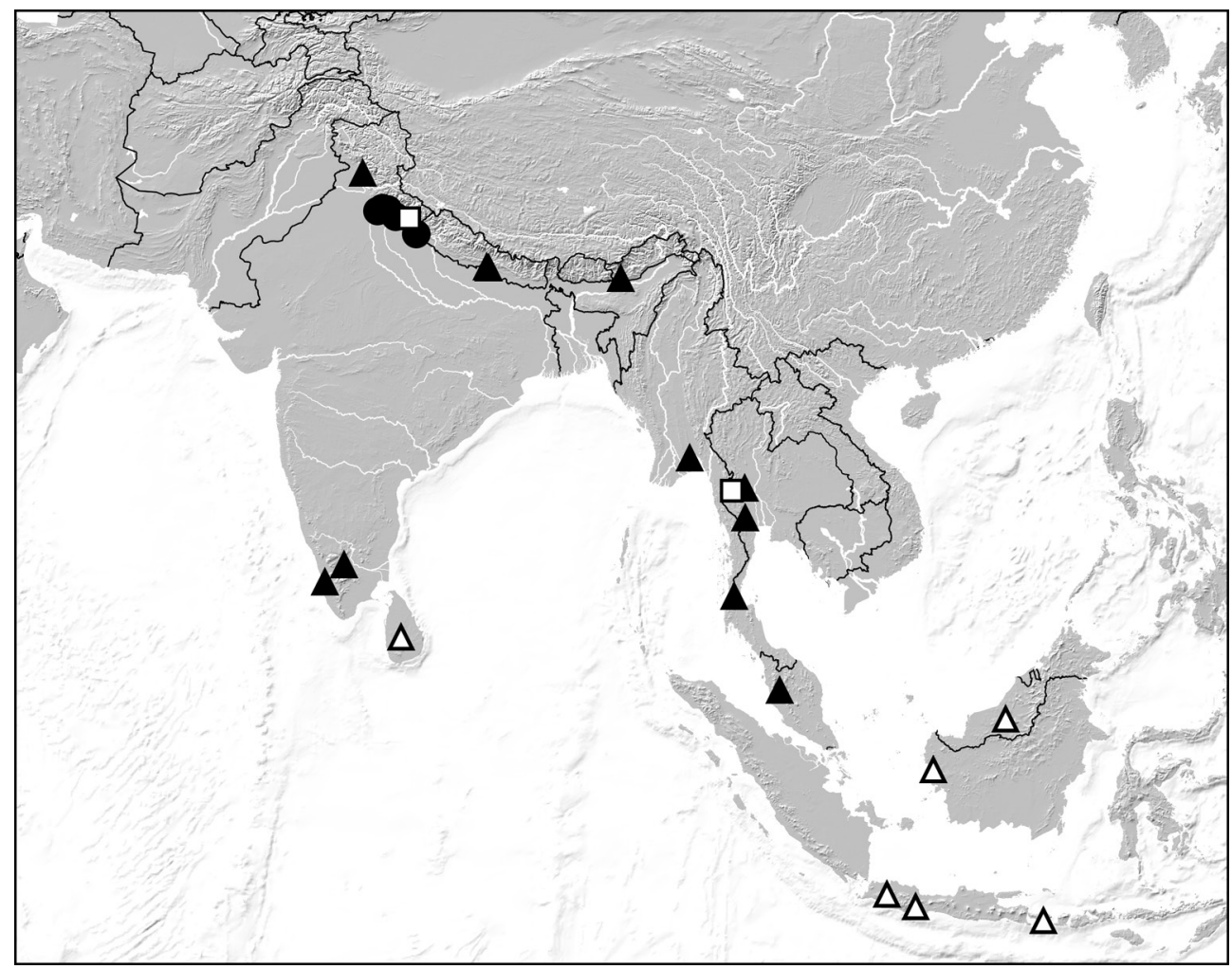

Map 3: Distributions of Pseudolathra pulchella (triangles; open triangles: female-based records), P. vellicans (filled circles), P. transversicollis (open squares), based on revised records. 
L. caffrum BoHeman, 1848 by Fauvel (1903), a species whose original description is based on an unspecified number of syntypes from "Caffraria orientali" (BoHEMAn 1848). Repeated loan requests addressed to the curator in charge at the natural history museum in Stockholm, where the Boheman collection is deposited, remained unanswered.

LAST (1966) figured the aedeagus of what he regarded as $P$. caffra, but failed to state if he had seen type material and what specimen his illustrations were based on. In any case, they show that the male he studied is not conspecific with the present interpretation of the $P$. pulchella, but probably with $P$. vellicans.

An examination of material from Kenya (one male and one female) and from South Africa (two females), which had been identified by Cameron as $P$. caffra, revealed that this material represents an externally highly similar and, based on the similar general morphology of the male sexual characters, closely related, but nevertheless distinct species. Furthermore, it is often impossible to reliably distinguish Pseudolathra species based on external characters alone, and the male sexual characters of true $P$. caffra had never been examined and illustrated. Therefore, it seems most unlikely that both names should refer to the same species and, until there is evidence proving otherwise, P. pulchella is revalidated. For illustrations of the aedeagus of $P$. caffra from Kenya see Figs 35-37.

Cameron (1940) described Lathrobium caffrum javanum based on "two examples" from "S. Java: Tjilatjap", stating that this subspecies was distinguished from the nominate subspecies by slightly smaller size, different coloration, and denser punctation of the head and pronotum. Only one syntype was located in the Cameron collection, although, according to the original description, both syntypes were deposited there. In external characters, the examined syntype is indistinguishable from material seen, e.g., from northern India. Hence the synonymy proposed above.

Additional material examined:

Nepal: 15 exs., Narayani, Chitawan, Gynganagar, at light, 9.V.2005, leg. Ahrens (NME, cAss); 1 \%, Narayani, Chitawan district, Chitawan National Park, Sauraha-Thati-Bagh Mare, 200-500 m, 17.-21.V.1996, leg. Pejetra [?] (cAss).

India: 9 exs., Assam, Bhalukpong, $27^{\circ} 02^{\prime} \mathrm{N}, 92^{\circ} 35^{\prime} \mathrm{E}, 150$ m, 26.V.-3.VI.2006, leg. Dembický \& Pacholátko (BMNH, cAss); 1 ․ Uttaranchal, Dehra Dun, VI.1932, leg. Champion (BMNH); 1 , Uttaranchal, Dehra Dun, Lachhiwala, 14.III.1922, leg. Cameron (BMNH); 1 o , Himachal Pradesh, Kangra, Narpur, ca. $1100 \mathrm{~m}$, leg. Champion (cAss); $1 \mathrm{o}^{\star}$, Tamil Nadu, Coimbatore prov., Tiruppur town, 18.-20.XI.2002, leg. Saluk (cSch); 2 ㅇ ㅇ, Kerala, Alwaye town, 15.-18.XI.2002, leg. Saluk (cSch, cAss).

Myanmar: 2 우, Pegu, $60 \mathrm{~km}$ NW Yangon, $17^{\circ} 19^{\prime} \mathrm{N}, 96^{\circ} 28^{\prime} \mathrm{E}$, light trap, 22.XI.2003, leg. Hornburg (cSch, cAss).

Thailand: 9 exs., Kanchanaburi, farmland near Kwai river, 400 m, 25.-27.III.1987, leg. Brendell (BMNH, cAss); 1 + , Chumphon prov., Pha To env., 948'N, 9847'E, 1.-12.III.1996, leg. Průdek (cSch); 3 exs., Uthai Thani, $65 \mathrm{~km} \mathrm{NW}$ Uthai Thani, $25 \mathrm{~km} \mathrm{NW}$ Lan Sak, $110 \mathrm{~m}$, light trap in rice fields and mixed cultures, V.1990, leg. Thielen (cSch).

Malaysia: 4 exs., W Ipoh, 5 km from Tanjong Rambutan, 13.-15.IV.2000, leg. M. Snižek (cSch, cAss); 1 ㅇ, Borneo, Sarawak, 4th Division, Gn. Mulu NP., near Base Camp, 50-100 m, at light, V-VIII.1978, leg. Hammond \& Marshall (BMNH).

Indonesia: 1 ㅇ, Bali, Ubud, Donpasar, light trap, 16.XI.-4.XII.1993, leg. Pankow (cAss); 1 ㅇ, Borneo, Pontianak (BMNH); 1 ㅇ, W-Java, Buitenzorg [= Bogor, 6 $\left.6^{\circ} 36^{\prime} \mathrm{S}, 106^{\circ} 47^{\prime} \mathrm{E}\right]$, at light, 16.IV.1923, leg. Pendlebury (BMNH).

\section{Redescription:}

Body length 5.7-7.0 mm; length of forebody 3.1-3.8 mm. Coloration variable: head usually blackish-brown to blackish, rarely reddish-brown; pronotum reddish; elytra usually blackishbrown to blackish (sometimes with weak bluish hue), rarely reddish-brown; abdomen uniformly 
reddish to uniformly blackish-brown, sometimes reddish with darker apex (segments VII-X); legs reddish; antennae reddish to brown.

Head approximately as broad as long; posterior angles usually broadly convex, weakly marked; punctation coarse and sparse, in median dorsal portion very sparse or absent; interstices without microsculpture and glossy. Eyes large, slightly shorter than distance between posterior margin of head and neck in dorsal view. Antennae slender, 2.0-2.4 mm long; all antennomeres oblong.

Pronotum of somewhat variable shape, 1.15-1.25 times as long as broad and usually 1.00-1.05 times as broad as head; on either side of the impunctate midline with series of 15-20 punctures, these punctures often accompanied by additional punctures; punctation of lateral portions sparse to moderately dense; interstices without microsculpture.

Elytra approximately as long as pronotum or indistinctly shorter; laterally with fine and almost complete submarginal carina; punctation arranged in distinct series; interstices without microsculpture. Hind wings fully developed. Protarsomeres with very weakly pronounced sexual dimorphism, in both sexes strongly dilated, only slightly less so in female than in male.

Abdomen slightly narrower than elytra; punctation very fine and very dense; interstices with microsculpture; posterior margin of tergite VII with palisade fringe.

$\mathrm{O}^{\mathrm{t}}$ : sternite VII without distinctly modified pubescence and shallow median impression, posterior margin truncate (Fig. 38); sternite VIII oblong, posterior excision narrowly V-shaped and deep, not quite reaching middle of sternite (Fig. 39); aedeagus 1.0-1.2 mm long, shaped as in Figs 33-34; ventral process of aedeagus conspicuously laterally compressed and apical portion of dorsal plate of distinctive shape.

\section{Comparative notes:}

Pseudolathra pulchella is distinguished from the preceding species by slightly larger body size, on average darker coloration of the elytra and of the head, an on average more oblong pronotum, the slightly broader posterior excision of the male sternite VIII, and by the completely different morphology of the aedeagus. It is readily separated from $P$. nigerrima and $P$. regularis by external characters alone, especially by the different coloration (P. nigerrima and P. regularis: body completely blackish).

\section{Distribution and natural history:}

This species is remarkably widespread, its revised distribution ranging from Nepal to Sri Lanka, Thailand, Malaysia, and Indonesia (Map 3). According to Fauvel (1903) and Cameron (1931), it has been recorded also from other parts of the Oriental region. However, in view of the similarity to other species, all previous records and all female-based records above should be considered doubtful. Little is known about the habitat of this species. The highest altitude specified on the labels of the examined material is $500 \mathrm{~m}$. On several occasions, the species was collected with light traps in March, May/June, and November. In one locality in southern central Nepal, the species was found together with P. unicolor and P. himalayana.

Pseudolathra vellicans sp. n. (Figs 40-44, Map 3)

\section{Type material:}

Holotype ơ: "Kheri Rau, Siwaliks. / Dr. M. Cameron. 30.X.1021. / M. Cameron. Bequest. B.M. 1955-147. / cafrum / Holotypus ơ Pseudolathra vellicans sp. n., det. V. Assing 2012” (BMNH). Paratypes: 1 \% : same data as holotype (cAss); 1 \%: "Kaldhunga, Haldwani Dn. 26.3. '23. HGC." 
(BMNH); 1 : "Timli, Siwaliks. / Dr. Cameron. 27.XI.21 / M. Cameron. Bequest. B.M. 1955147. / cafrum" (BMNH); 1 o", 1 \% : "Haldwani Dist. Kumaon, India. H. G. C. / G.C. Champion coll. B.M. 1927-409” (BMNH, cAss); 1 : : "Mohan Rau, Siwaliks, U.P. / Dr. Cameron. 12.10.21. / M. Cameron. Bequest. B.M. 1955-147. / cafrum” (BMNH); 2 ㅇ ㅇ : "India: U.P., Saharanpur Div., Siwalik Hills, 8.iv.1928. H.G. Champion. / cafrum" (BMNH).

\section{Comment:}

This species is evidently conspecific with LAsT's (1966) interpretation of $P$. caffra, as is suggested by his schematic drawing of the aedeagus.

\section{Etymology:}

The specific epithet (present participle of the Latin verb vellicare: to pinch) alludes to the pair of claw-like apical structures of the aedeagus.

\section{Description:}

Body length 5.8-7.8 mm; length of forebody 3.05-3.50 mm. Coloration variable: head reddish to blackish; pronotum reddish; elytra brown to blackish, along suture, lateral and posterior margins, and at humeral angles usually more or less extensively reddish; abdomen reddish to dark-brown; legs and antennae yellowish to reddish yellow.

Dorsal portion of head almost impunctate; punctures usually confined to lateral and posterior portions. Antennae rather fine and short, approximately $2.0 \mathrm{~mm}$ long. Other external characters as in P. pulchella.

$\sigma^{7}$ : sternite VII not distinctly modified; sternite VIII distinctly oblong, posterior excision narrow, sharply acute at apex, and deep, its depth approximately half the length of sternite (Fig. 40); aedeagus conspicuously large in relation to body size, $1.4 \mathrm{~mm}$ long, and of highly distinctive shape: apically with pair of claw-shaped structures extending beyond apex of dorsal plate (Figs 41-42); ventral process slender, laterally compressed, somewhat dagger-shaped in lateral view, and apically distinctly bifid in ventral view (Figs 43-44).

\section{Comparative notes:}

Pseudolathra vellicans is distinguished from the highly similar P. pulchella only by the slightly shorter and finer antennae (in P. pulchella usually longer than $2.0 \mathrm{~mm}$ and slightly more massive), the on average more extensively impunctate dorsal surface of the head, the different shape of the male sternite VIII, and particularly by the completely different morphology of the aedeagus.

\section{Distribution:}

This species is currently known only from several localities in Uttaranchal and Uttar Pradesh, northern India.

Pseudolathra nigerrima (CAMERoN, 1924), comb. n. (Figs 45-51, Map 2)

Lathrobium nigerrimum CAMERON, 1924: $192 \mathrm{f}$.

\section{Type material examined:}

Lectotype ơ , present designation: "Malhan Range, Siwaliks. Dr. Cameron, 24.IX.22. / Lathrobium nigerrimum Cam. / H. Stevens. Brit. Mus. 1922-307. / Type / M. Cameron. Bequest. B.M. 1955147. / Lectotypus o Lathrobium nigerrimum Cameron, desig. V. Assing 2011 / Pseudolathra nigerrima (Cameron), det. V. Assing 2011" (BMNH). Paralectotype ơ: "Arni Gad. Mussoorie 

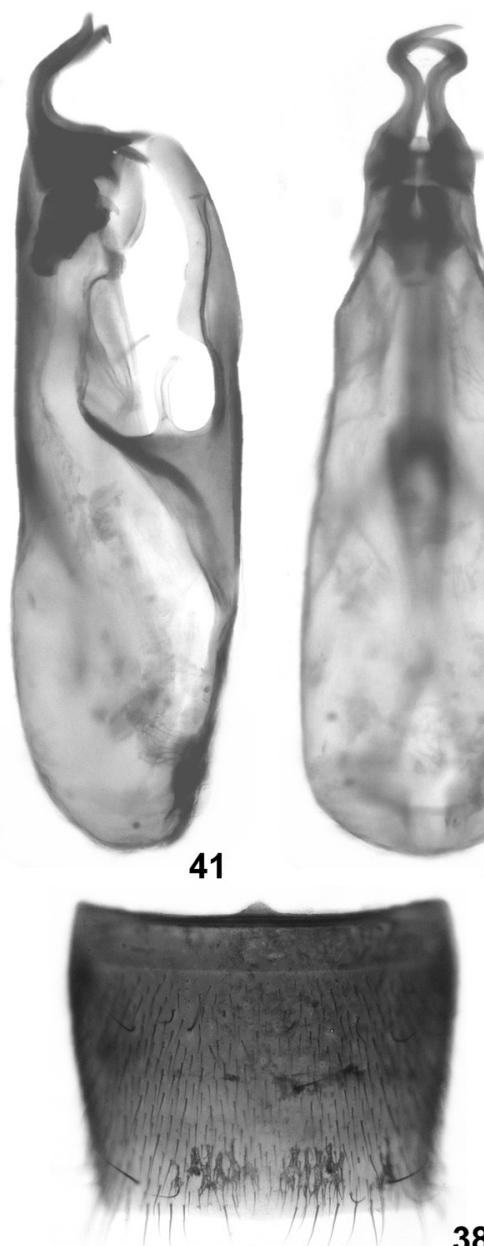

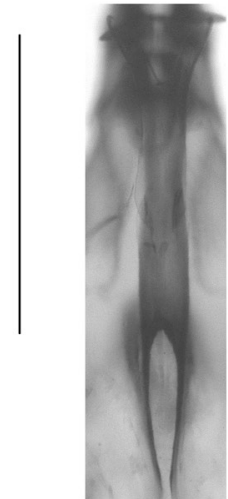

43
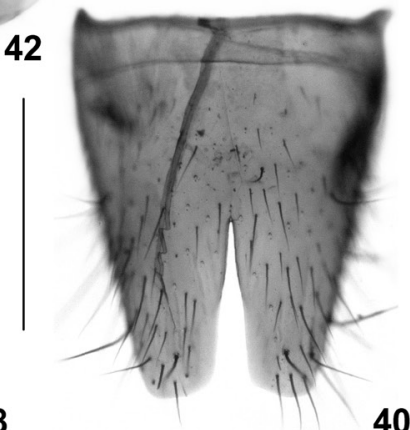

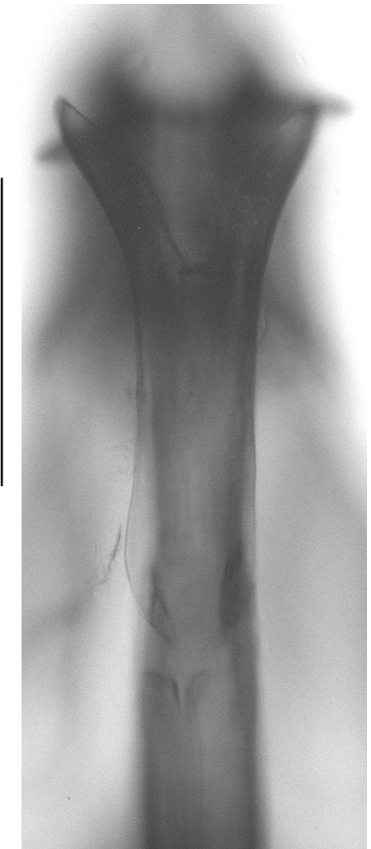

44

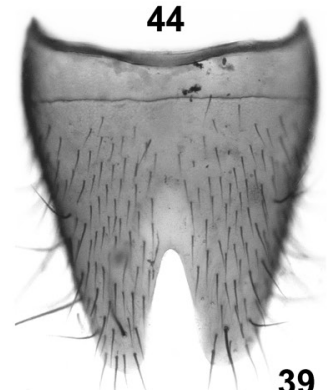

Figs 38-44: Pseudolathra pulchella from Malaysia (38-39) and P. vellicans (40-44): male sternite VII (38); male sternite VIII (39-40); aedeagus in lateral and in ventral view (41-42); ventral process of aedeagus in ventral view (43); apex of ventral process of aedeagus in ventral view (44). Scale bars: $38-43$ : $0.5 \mathrm{~mm}$; 44: $0.2 \mathrm{~mm}$.

/ Dr. Cameron, 28.V.21 / Cotype / L. nigerrimum Cam / Lathrobium nigerrimum Cameron / Coll. W. Champman in Coll. P. Griveau, MHNG - 2007 / nigerrimum Cam. / Paralectotypus Lathrobium nigerrimum Cameron / Pseudolathra nigerrima (Cameron), det. V. Assing 2011" (MHNG).

\section{Comment:}

The original description is based on an unspecified number of syntypes, among them at least one male, from "Siwaliks; Mussorie District; Arni Gad, Kaligad" (CAmeron 1924). A male syntype was located in the collections of the BMNH; an additional male syntype was found in the collections of the MHNG. The specimen deposited in the BMNH is in better condition and designated as the lectotype. An examination of these specimens revealed that the species belongs to Pseudolathra. 
Additional material examined:

Nepal: 2 우 으, Ilam district, between Mai Pokhari and Ilam, 1330 m, arable land, 1.IV.1980, leg. Martens \& Ausobsky (SMNS, cAss); $10^{\star}$, trail from Pokhara to Ghoropani, leg. Franz (NHMW); 1 [teneral], Phulchoki, near Dalikhel, 2000 m, leg. Franz (NHMW).

India: 3 exs., Haldwani District, Kumaon, leg. Champion (BMNH, cAss).

\section{Redescription:}

Body length 7.0-9.5 mm; length of forebody 4.0-4.4 mm. Habitus as in Fig. 45. Coloration: head and abdomen black; pronotum and elytra blackish-brown; legs and antennae dark-yellowish.

Head (Fig. 46) distinctly transverse, approximately 1.15 times as broad as long; posterior angles marked; dorsal surface with few macropunctures laterally and with sparse micropunctation; interstices without microsculpture. Eyes large, more than twice as long as postocular region in dorsal view. Antenna long and slender, almost $3 \mathrm{~mm}$ long.

Pronotum (Fig. 46) approximately as long as broad and approximately 1.05 times as wide as head, lateral margins straight, weakly converging posteriorly in dorsal view, posterior angles broadly rounded; on either side of midline with a dorsal series of 6-7 coarse punctures, laterad of these series with very few macropunctures; micropunctation very sparse; microsculpture absent.

Elytra (Fig. 46) almost 0.9 times as long as pronotum, humeral angles marked; macropunctation arranged in one sutural and three dorsal series; microsculpture and micropunctation absent. Hind wings probably fully developed.

Abdomen narrower than elytra; punctation very fine and rather sparse; posterior margin of tergite VII with palisade fringe.

$\mathrm{o}^{\text {t: }}$ : tergite VIII strongly convex posteriorly; sternite VII posteriorly weakly and broadly concave, on either side of middle with comb of stout, black, spine-like setae increasing in length and stoutness laterad (Fig. 47); sternite VIII oblong, with deep and narrow posterior excision almost reaching middle of sternite (Fig. 48); aedeagus approximately $1.1 \mathrm{~mm}$ long, shaped as in Figs 49-51.

\section{Comparative notes:}

This species is readily distinguished from all the preceding species by the different morphology of the aedeagus, darker coloration, and larger size.

\section{Distribution:}

This species has been recorded from several localities in North India and Nepal (CAmeron 1931, Coiffait 1975).

\section{Pseudolathra transversicollis sp. n. (Figs 52-58, Map 3)}

\section{Type material:}

Holotype $0^{\top}$ : “W.Thailand: $300 \mathrm{~m}$., Thung Yai Wildlife Sanctuary, $15^{\circ} 28^{\prime} \mathrm{N}-98^{\circ} 48^{\prime} \mathrm{E} / \mathrm{Tak}$ Province, Umphang District, Song Bae Stream. 18-27.iv.1988. / Evergreen rain forest. M.J.D. Brendell. B.M. 1088-183 / Flight interception trap / Holotypus o Pseudolathra transversicollis sp. n., det. V. Assing 2012“ (BMNH). Paratypes: $11 \sigma^{\star} \sigma^{\star}, 4$ ㅇ $\circ$ : same data as holotype (BMNH, cAss); 2 o $^{\star}$ : "Haldwani Dist., Kumaon, India. H.G.C. / H.G. Champion coll. B.M. 1927-409" (BMNH, cAss).

\section{Etymology:}

The specific epithet (Latin, adjective) refers to the usually transverse pronotum. 


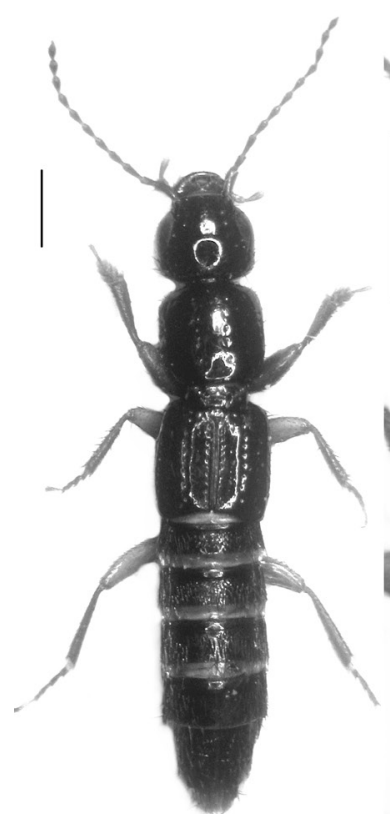

45

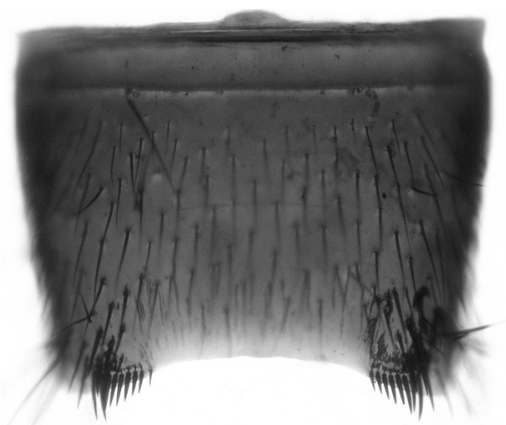

47

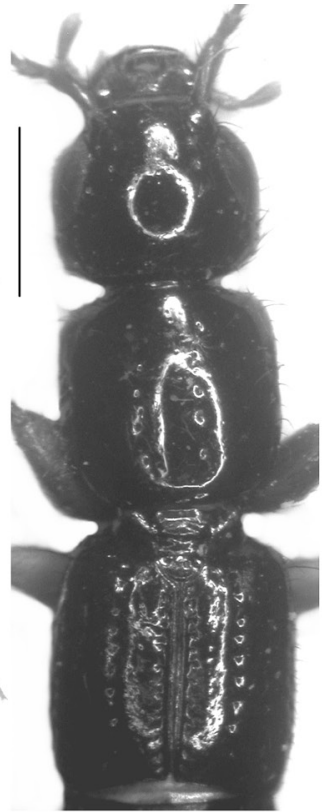

46

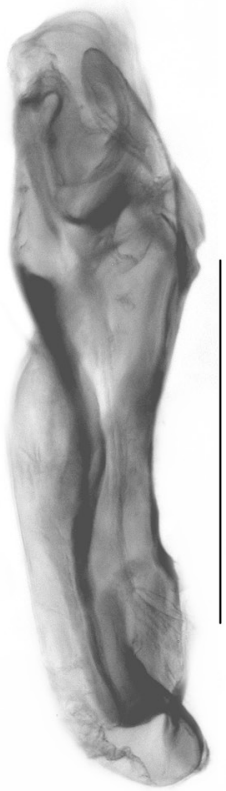

49

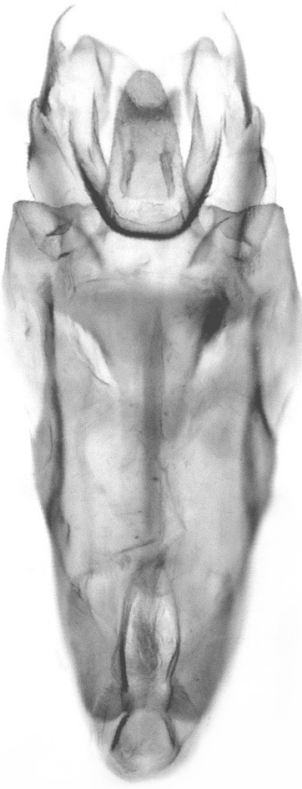

50

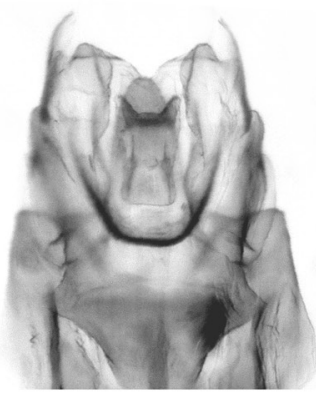

51

Figs 45-51: Pseudolathra nigerrima, lectotype: habitus (45); forebody (46); male sternite VII (47); male sternite VIII (48); aedeagus in lateral and in ventral view (49-50); apical portion of aedeagus in ventral view (51). Scale bars: 45-46: $1.0 \mathrm{~mm}$; 47-51: $0.5 \mathrm{~mm}$.

\section{Description:}

Large species: body length 9.0-10.5 mm; length of forebody 4.5-5.0 mm. Coloration: head and pronotum black, with the posterior and often also the anterior margins diffusely dark-reddish; elytra reddish to reddish-brown, posteriorly often weakly and diffusely infuscate; abdomen black, with the posterior and lateral margins of the tergites reddish; legs dark-yellowish; antennae reddish. Head (Fig. 52) strongly transverse, approximately 1.2 times as wide as long; posterior angles obtusely marked; dorsal surface conspicuously glossy, almost impunctate, except for the sparse micropunctation and for a few coarse macropunctures near eyes and near posterior margin. Eyes large and bulging, approximately 3 times as long as postocular region in dorsal view. Antenna approximately 3.2-3.5 mm long; antennomeres III-X with very narrow bases, distinctly dilated apically. 
Pronotum (Fig. 52) usually weakly transverse, 1.00-1.05 times as broad as long and slightly wider than head; dorsal series composed of usually 5-6 coarse punctures; lateral portions with very sparse coarse punctures; surface glossy and with sparse micropunctation.

Elytra (Fig. 53) nearly as long as pronotum; laterally with fine and complete submarginal carina; punctation arranged in three series, one along suture, one in the middle, and one near lateral margin; interstices with micropunctation and glossy. Hind wings fully developed. Protarsomeres without appreciable sexual dimorphism, in both sexes strongly dilated.

Abdomen distinctly narrower than elytra; punctation moderately coarse and dense on tergite III, gradually becoming finer and less dense on tergites IV-VII; interstices with shallow microsculpture, but glossy; posterior margin of tergite VII with palisade fringe.

$0^{\star}$ : sternite VII with distinctly concave posterior margin (Fig. 57); sternite VIII oblong, posterior excision narrow and deep, its depth approximately $2 / 5$ the length of sternite (Fig. 58); aedeagus large, 1.4-1.5 mm long, with short ventral process with apex of triangular shape and subapically with two minute teeth (lateral view) (Figs 53-56).

\section{Intraspecific variation:}

Slight differences between the males from Thailand and those from northern India were observed in the morphology of the aedeagus (see Figs 53-54 and Figs 55-56, respectively). However, the two specimens from northern India were collected almost a century ago and the apical parts of the aedeagus are somewhat (semi-)membranous, so that the observed differences may be based on artefacts. Moreover, the distance between Thailand and northern India is considerable, which would account for some clinal variation, and the differences between the aedeagi of different species are usually rather pronounced. Therefore, in the absence of additional morphological evidence, the observed differences are attributed to intra- rather than interspecific variation. More material, particularly from northern India, is needed to clarify if the observed differences are constant.

\section{Comparative notes:}

Pseudolathra transversicollis is distinguished from all other Palaearctic and Oriental congeners by larger size, the distinctive coloration, the usually slightly transverse pronotum, the shape of the male sternite VII, and by the shape of the aedeagus. Based on the similarly derived morphology of the aedeagus and similar external characters, $P$. transversicollis is undoubtedly most closely related to $P$. nigerrima, apparently its adelphotaxon. From this species, it is additionally separated by the different shape and chaetotaxy of the male sternite VII.

\section{Distribution and natural history:}

At present, $P$. transversicollis is known from one locality in Uttaranchal, northern India, and one locality in western Thailand, where the specimens were collected with flight interception traps in an evergreen rain forest at an altitude of $300 \mathrm{~m}$.

Pseudolathra sagittata sp. n. (Figs 59-63, Map 2)

\section{Type material:}

Holotype ơ: “W.Thailand: 300 m., Thung Yai Wildlife Sanctuary, $15^{\circ} 28^{\prime} \mathrm{N}-98^{\circ} 48^{\prime} \mathrm{E} / \mathrm{Tak}$ Province, Umphang District, Song Bae Stream. 18-27.iv.1988. / Evergreen rain forest. M.J.D. Brendell. B.M. 1088-183 / Flight interception trap / Holotypus o Pseudolathra sagittata sp. n., det. V. Assing 2012“ (BMNH). Paratypes: $20^{\star} \sigma^{\star}, 2$ ㅇ 오 : same data as holotype (BMNH, cAss); 


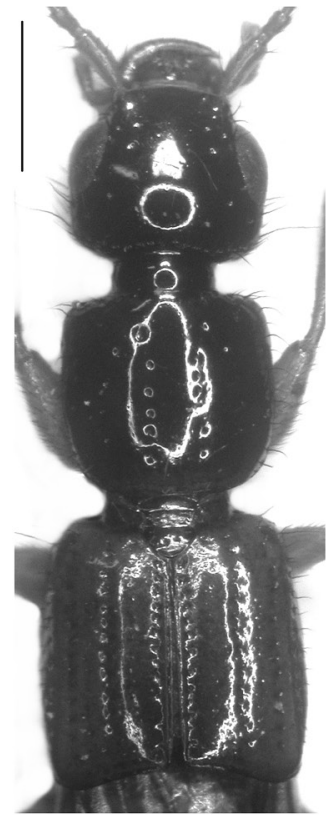

52

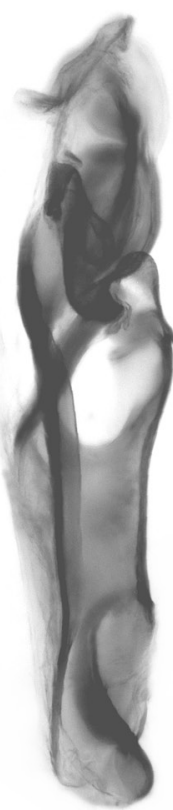

53

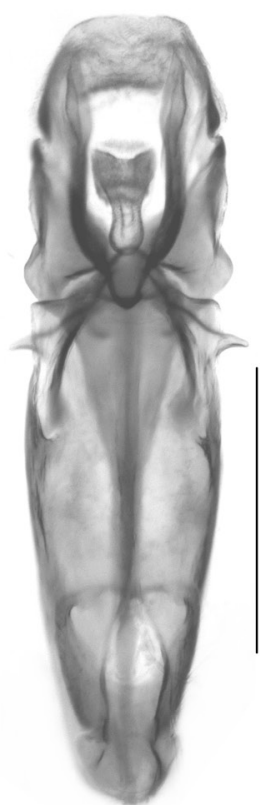

54

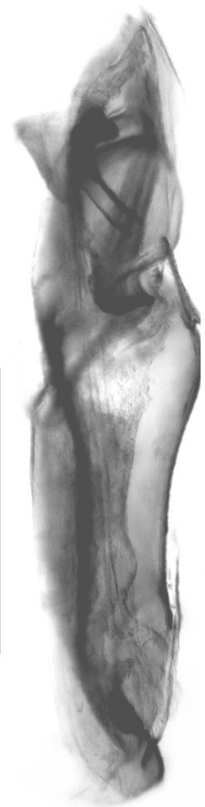

55

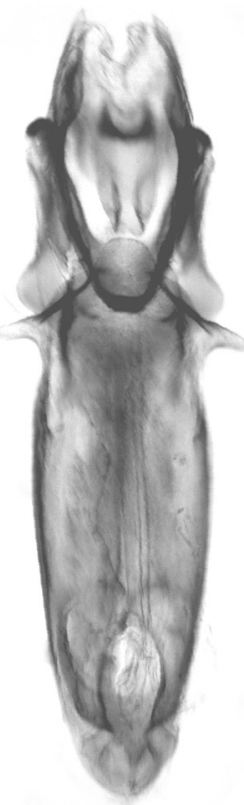

56

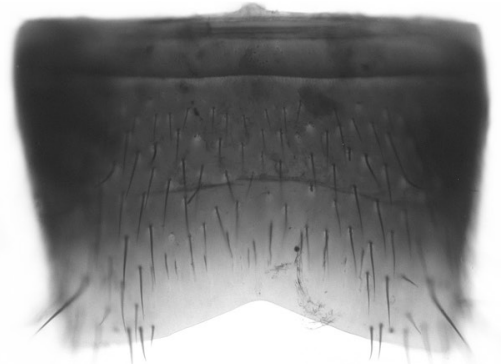

57

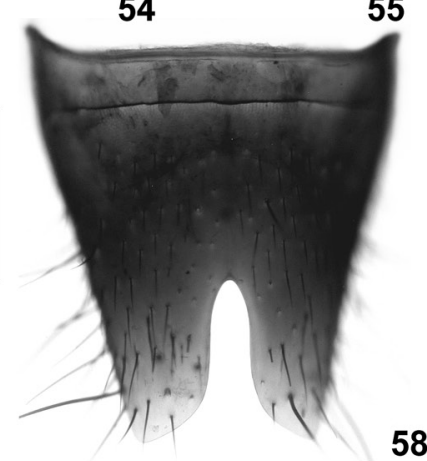

58

Figs 52-58: Pseudolathra transversicollis from Thailand (52-54) and northern India (55-58): forebody (52); aedeagus in lateral and in ventral view (53-56); male sternite VII (57); male sternite VIII (58). Scale bars: 52: $1.0 \mathrm{~mm}$; 53-58: $0.5 \mathrm{~mm}$.

2 ơ $^{\star}$ : “W.Thailand: 300 m., Thung Yai Wildlife Sanctuary, $15^{\circ} 30^{\prime} \mathrm{N}-98^{\circ} 48^{\prime} \mathrm{E} /$ Tak Province, Umphang District, Mae Chan/Mae Klong confluence. 27.iv.-6.v.1988. / Oak/bamboo forest. M.J.D. Brendell. B.M. 1088-183 / Flight interception trap“ (BMNH, cAss).

\section{Etymology:}

The specific epithet (Latin, adjective: arrow-shaped) refers to the shape of the apex of the dorsal plate of the aedeagus.

\section{Description:}

Body length 6.5-7.5 mm; length of forebody 3.5-4.0 mm. Habitus as in Fig. 59. Coloration: body black; legs dark-yellowish; antennae pale-reddish. 
Head (Fig. 60) strongly transverse, 1.20-1.25 times as wide as long; posterior angles obtusely marked; dorsal surface conspicuously glossy, almost impunctate, except for a few punctures near eyes and near posterior margin. Eyes large and bulging, 3-4 times as long as postocular region in dorsal view. Antenna approximately $2.3 \mathrm{~mm}$ long; antennomeres III-X with very narrow bases, distinctly dilated apically.

Pronotum (Fig. 60) almost as broad as long and approximately as broad as head; dorsal series composed of usually 5-6 coarse punctures; lateral portions with very sparse coarse punctures; surface conspicuously glossy.

Elytra (Fig. 60) 0.90-0.95 times as long as pronotum; laterally with fine and complete submarginal carina; punctation arranged in three series, one along suture, one in the middle, and one near lateral margin; interstices without microsculpture and very glossy. Hind wings fully developed. Protarsomeres without appreciable sexual dimorphism, in both sexes strongly dilated.

Abdomen distinctly narrower than elytra; punctation rather coarse and very dense on tergite III, gradually becoming finer and less dense on tergites IV-VII; interstices without microsculpture and glossy; posterior margin of tergite VII with palisade fringe.

$0^{t}$ : sternite VII not distinctly modified; sternite VIII oblong, posterior excision narrow and deep, not quite reaching middle of sternite (Fig. 63); aedeagus 1.0-1.1 mm long, slender, with apically deeply bifid ventral process, and with apically somewhat arrow-shaped dorsal plate in ventral view (Figs 61-62).

\section{Comparative notes:}

In external appearance, $P$. sagittata somewhat resembles $P$. nigerrima, from which it is distinguished by smaller size (no overlap), paler legs, the distinctly coarser punctation of the anterior abdominal tergites, as well as by the sexual characters, particularly the completely different shape of the aedeagus.

\section{Distribution and natural history:}

Pseudolathra sagittata is known from two localities in western Thailand (Map 2). The specimens were collected with flight interception traps in an evergreen rain forest and in a mixed oak and bamboo forest at an altitude of $300 \mathrm{~m}$.

Pseudolathra regularis (SHARP, 1889), comb. n. (Figs 64-70, Map 2)

Lathrobium regulare SHARP, 1889: 258.

Type material examined:

Lectotype ${ }^{\star}$, present designation: “ ${ }^{\star}$ Lathrobium regulare. Type D.S., Yokohama. Lewis [written on mounting label] / Japan. G. Lewis / Type / Sharp Coll, 1905-313. / Pseudolathra regulare (Sharp) o $\sigma^{*}$, V.I. Gusarov det. 1992 / Aedeagus at rest is turned to $180^{\circ}$ in abdomen / Lectotypus $\sigma^{*}$ Lathrobium regulare Sharp, desig. V. Assing 2012 / Pseudolathra regularis (Sharp), det. V. Assing 2012” (BMNH).

\section{Comment:}

The original description is based on "six examples" from "Yokohama" (SHARP 1889). The male syntype made available to me from the Sharp collection is designated as the lectotype.

SHARP (1889) stated that L. regulare was a "species of the L. lusitanicum group", which today belongs to Pseudolathra. An examination of the lectotype confirmed that the species indeed belongs to this genus. 


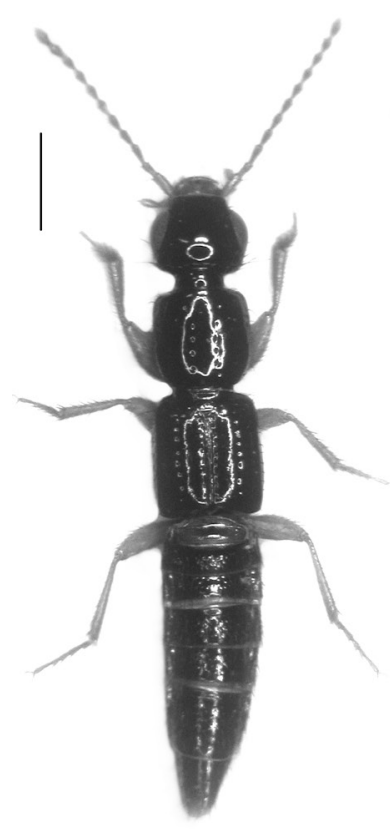

59

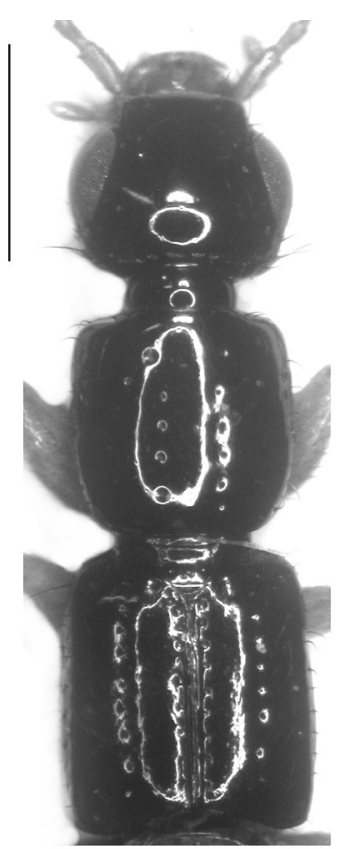

60

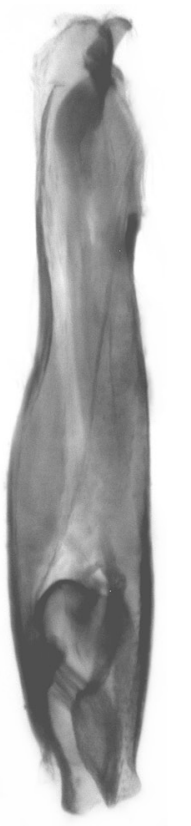

61

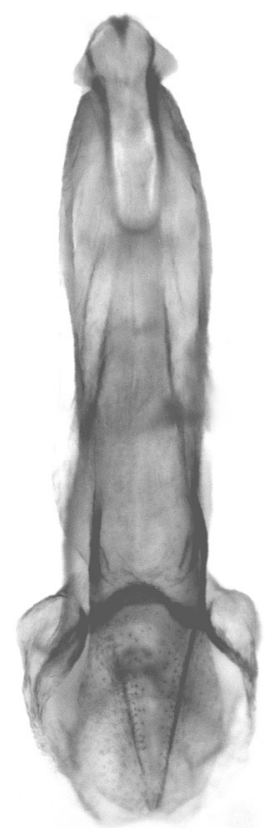

62

Figs 59-62: Pseudolathra sagittata: habitus (59); forebody (60); aedeagus in lateral and in ventral view (61-62). Scale bars: 59-60: $1.0 \mathrm{~mm}$; 61-62: $0.5 \mathrm{~mm}$.

\section{Additional material examined:}

China: 1 ex., N-Sichuan, Daba Shan, $65 \mathrm{~km} \mathrm{~N}$ Fengjie, 3140'N, 109³4'E, $1000 \mathrm{~m}$, gravel river bank, 10.VII.2001, leg. Wrase (cSch); 2 exs., Shaanxi, $7 \mathrm{~km} \mathrm{E} \mathrm{Zhouzhi,} \mathrm{auto} \mathrm{route} \mathrm{100,} \mathrm{km} \mathrm{72,} \mathrm{tributary} \mathrm{of} \mathrm{Wei}$ He river, $34^{\circ} 09^{\prime} \mathrm{N}, 108^{\circ} 17^{\prime} \mathrm{E}, 400 \mathrm{~m}, 24$.VIII.1995, leg. Wrase (cSch, cAss); 1 ex., Shaanxi, Xian, Ba R. Br., 18.IX.1980, leg. Hammond (BMNH); 1 ex., Yunnan, Dali Bai Aut. Pref., 10 km S Weishan, Hóu Hé river bank, $25^{\circ} 09^{\prime} \mathrm{N}, 100^{\circ} 20^{\prime} \mathrm{E}, 1650 \mathrm{~m}$, washed from sand and gravel, 15.IX.2009, leg. Schülke (cSch); 3 우 우, Jiangsu, Nanjing, Agricultural University, VII.1991, leg. Cooter (MMUM, cAss).

\section{Redescription:}

Body length 6.0-7.0 mm; length of forebody 3.2-3.9 mm. Habitus as in Fig. 64. Coloration: forebody blackish, with the suture indistinctly dark-reddish; abdomen blackish, sometimes with dark-reddish apex; legs and antennae pale-reddish.

Head (Fig. 65) weakly oblong, approximately 1.05 times as long as broad, slightly tapering behind eyes; posterior angles rather weakly marked; dorsal surface with few macropunctures and with sparse micropunctation; interstices without microsculpture. Eyes large, approximately as long as postocular region in dorsal view, or slightly shorter. Antenna moderately slender, almost $2 \mathrm{~mm}$ long.

Pronotum (Fig. 65) about 1.20-1.25 times as long as broad and approximately 1.1 times as wide as head, lateral margins almost straight, weakly converging posteriorly in dorsal view, posterior angles broadly rounded; on either side of midline with a dorsal series of 11-14 coarse punctures, laterad of these series with sparse macropunctures; microsculpture very sparse, micropunctation absent. 


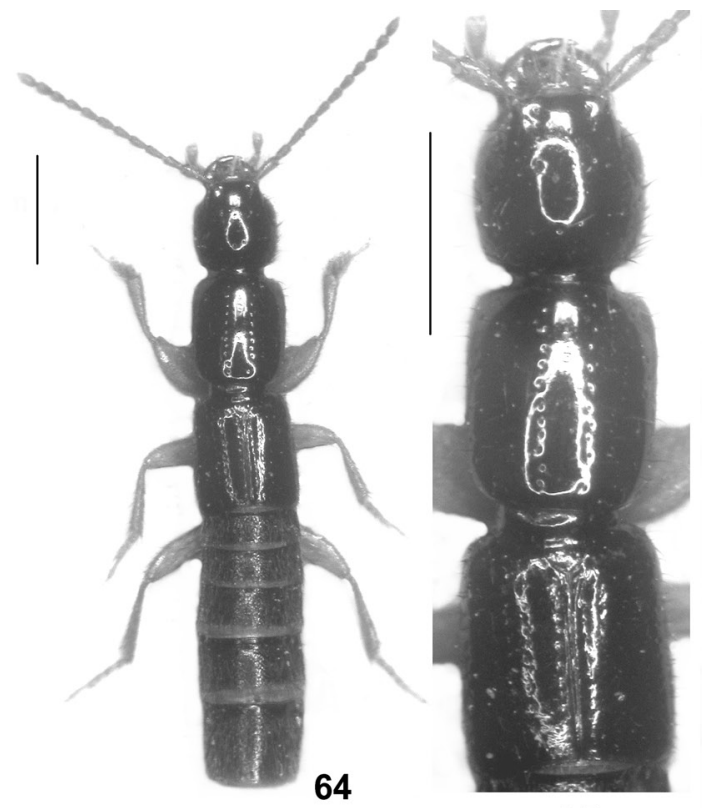

65

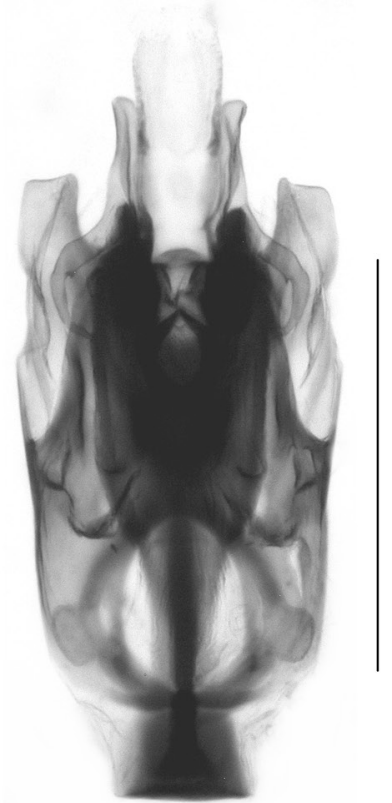

69

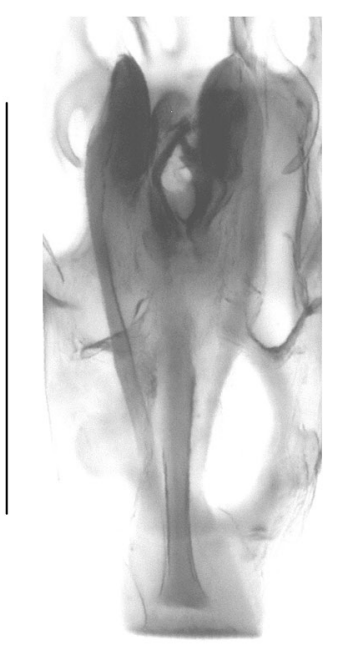

70
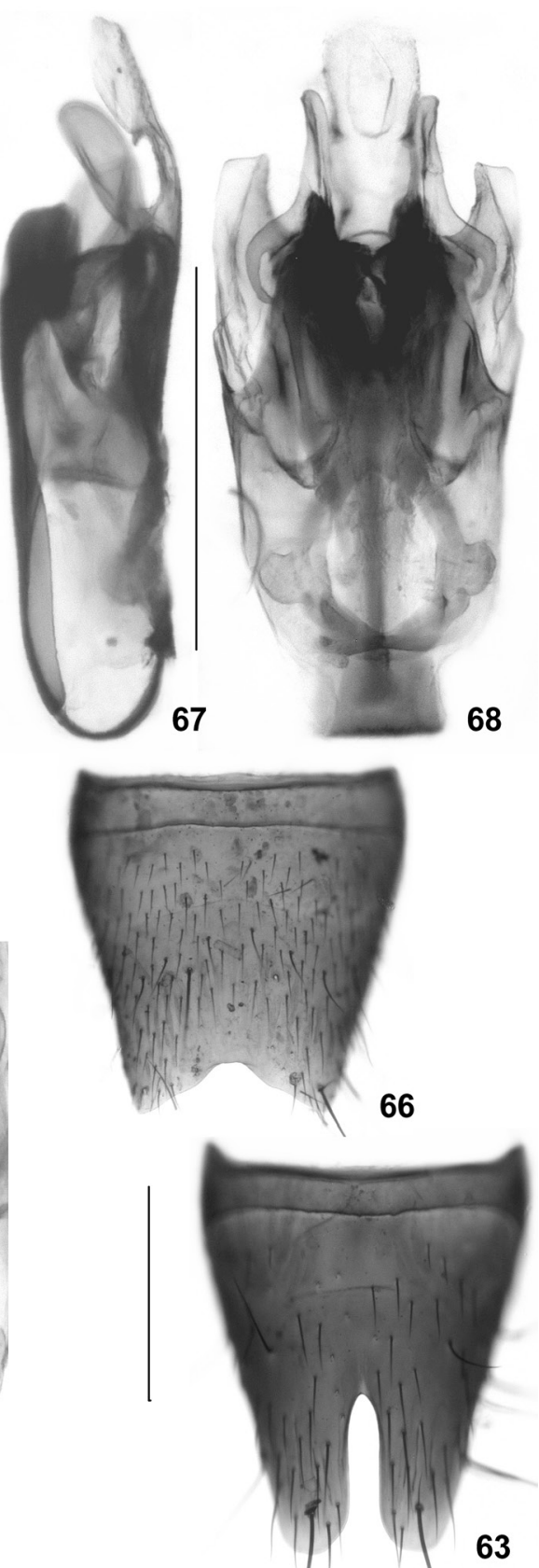

Figs 63-70: Pseudolathra sagittata (63) and P. regularis (64-70), lectotype (64-65, 67-68, 70) and male from China $(66,69)$ : male sternite VIII $(63,66)$; habitus $(64)$; forebody $(65)$; aedeagus in lateral and in ventral view (67-69); dorsal plate of aedeagus in dorsal view (70). Scale bars: 64-65: $1.0 \mathrm{~mm}$; 63, 66-70: 0.5 mm. 
Elytra (Fig. 65) approximately 0.8 times as long as pronotum, humeral angles marked; macropunctation arranged in one sutural and three dorsal series; microsculpture and micropunctation absent. Hind wings fully developed.

Abdomen approximately as broad as elytra; punctation fine and dense; posterior margin of tergite VII with palisade fringe.

$\sigma^{*}$ : tergite VIII strongly convex posteriorly; sternite VII without conspicuous modifications; sternite VIII weakly transverse, with rather broad and shallow posterior excision (Fig. 66); aedeagus 0.95-1.00 mm long, shaped as in Figs 67-70.

\section{Comparative notes:}

This species is distinguished from all other Palaearctic and Oriental species by the shallow and broad posterior excision of the male sternite VIII and by the shape of the aedeagus, from all other dark-coloured species also by the much more slender pronotum.

\section{Distribution:}

The species was described from Japan and subsequently reported also from China (Li \& CHEN 1990). In view of the external similarity of Pseudolathra species, as well as the fact that it was previously attributed to Lobrathium and that illustrations of the male sexual characters had been unavailable, there is some doubt if these records are based on correct identifications. Nevertheless, the species is present and widespread in China, as is confirmed by the above material from Shaanxi, Sichuan, Jiangsu, and Yunnan provinces.

\section{Acknowledgements}

I am indebted to the colleagues indicated in the material section for the loan of material under their care, to Alfred F. Newton (Chicago) for providing diversity figures for North America, to Zubair Ahmed (Karachi) for making Staphylinidae from Pakistan available, and to Benedikt Feldmann (Münster) for proof-reading the manuscript.

\section{References}

Assing, V. 2012: A revision of East Palaearctic Lobrathium (Coleoptera: Staphylinidae: Paederinae). - Bonn. Zoological Bulletin 61 (1): 49-128.

Assing, V. in press: A revision of the Lathrobium species of the Himalaya (Coleoptera: Staphylinidae: Paederinae). - Bonn. Zoological Bulletin (2012).

Bонас̌, J. 1988: Descriptions of new species of the subfamily Paederinae (Coleoptera, Staphylinidae) from the Palaearctic region. - Acta Entomologica Bohemoslovaca 85: 434-443.

Boheman, C. H. 1848: Insecta Caffraria annis 1838-1845 a J. A. Wahlberg collecta. Pars I. Fascic. I. Coleoptera. (Carabici, Hydrocanthari, Gyrinii et Staphylinii). - Holmiae: Norstedt: i-vii, 1-297.

Cameron, M. 1924: New species of Staphylinidae from India. - The Transactions of the Entomological Society of London 1924: 160-198.

Cameron, M. 1931: The Fauna of British India including Ceylon and Burma. Coleoptera, Staphylinidae. Volume 2. - London, Taylor and Francis: viii +257 pp.

Cameron, M. 1940: New species of Staphylinidae (Col.) from Java. - The Entomologist's Monthly Magazine 76: 181-184.

Cameron, M. 1950: Contribution à l'étude de l'Aïr. Coléoptères Staphylinidae. - Mémoires de l'Institut Français d'Afrique Noire 10: 212-215.

Coiffart, H. 1975: Xantholininae, Paederinae et Euaesthetinae récoltés au Népal par le professeur Franz (Coleoptera, Staphylinidae). - Nouvelle Revue d’Entomologie 5 (2): 153-186. 
Coiffart, H. 1982a: Staphylinides nouveaux d'Arabie Saoudite. - Bulletin de la Société d'Histoire Naturelle de Toulouse 117: 203-206.

Coiffart, H. 1982b: Coléoptères Staphylinidae de la région paléarctique occidentale. IV. Sous famille Paederinae. Tribu Paederini 1 (Paederi, Lathrobii). - Supplement à la Nouvelle Revue d'Entomologie 12 (4): $1-440$.

Fauvel, A. 1903: Mission de M. Maurice Maindron dans l'Inde méridionale. - Revue d'Entomologie 22: 149-163.

Fauvel, A. 1904: Staphylinides de l'Hindoustan et de la Birmanie. - Revue d'Entomologie 23: 43-70.

Gemminger, M. \& Harold, B. de 1868: Catalogus Coleopterorum hucusque descriptorum synonymicus et systematicus. Tom. II. Dytiscidae, Gyrinidae, Hydrophilidae, Staphylinidae, Pselaphidae, Gnostida, Paussidae, Scydmaenidae, Silphidae, Trichopterygidae, Scaphidiidae. - Monachii, E. H. Gummi: 425-752.

Herman, L. H. 2003: Nomenclatural changes in the Paederinae (Coleoptera: Staphylinidae). - American Museum Novitates 3416: 1-28.

KraAtz, G. 1859: Die Staphylinen-Fauna von Ostindien, insbesondere der Insel Ceylan. - Archiv für Naturgeschichte 25: 1-196.

Last, H. R. 1966: Coleoptera from Southeast Asia (IV). 3. Family Staphylinidae. - Memoirs of the Faculty of Liberal Arts and Education, Kagawa University, Part II, No. 135: 1-10.

Last, H. R. 1984: Recorded and new species of Coleoptera (Staphylinidae, Paederinae) in Papua New Guinea. - Folia Entomologica Hungarica 45 (2): 109-125.

Li, J. \& Chen, P. 1990: The fauna distribution of Staphylinidae in northeastern China [translation of Chinese title]. - Journal of Northeast Normal University 1: 13-20.

Löbl, I. \& Smetana, A. 2004: Catalogue of Palaearctic Coleoptera. Volume 2. Hydrophiloidea - Histeroidea - Staphylinoidea. - Stenstrup, Apollo Books: 942 pp.

Motschulsky, V. 1858: Énumeration des nouvelles espèces de coléoptères rapportés de ses voyages. Bulletin de la Société Impériale des Naturalistes de Moscou 31 (2): 634-670.

Newton, A. F.; Thayer, M. K.; Ashe, J. S. \& Chandler, D. S. 2001: Superfamily Staphylinoidea Latreille, 1802, Staphyliniformia Lameere, 1900; Brachelytra auctorum. 22. Staphylinidae Latreille, 1802. - In: Arnett, R. H. Jr. \& Thomas, M. C.: American Beetles. Archostemata, Myxophaga, Adephaga, Polyphaga: Staphyliniformia. Volume 1. - CRC Press, Boca Raton etc.: 272-418.

Sharp, D. S. 1889: The Staphylinidae of Japan. - The Annals and Magazine of Natural History (6) 3: 28-44, 108-121, 249-267, 319-334, 406-419, 463-476.

Smetana, A. 2004: Subfamily Paederinae Fleming, 1821. - In: Löbl, I. \& Smetana, A. (eds.): Catalogue of Palaearctic Coleoptera. Volume 2. Hydrophiloidea - Histeroidea - Staphylinoidea. - Apollo Books, Stenstrup: 579-624.

\section{Author's address:}

Dr. Volker Assing

Gabelsbergerstr. 2

30163 Hannover, Germany

e-mail: vassing.hann@t-online.de

\section{Subject Editor:}

Dr. L. ZerChe 